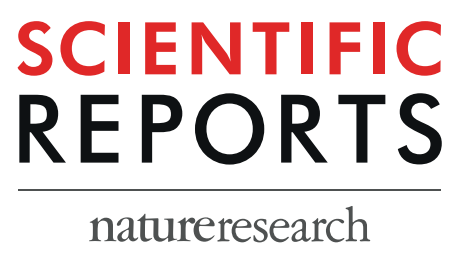

\title{
OPEN Nitrogen fertilizer regulates soil respiration by altering the organic carbon storage in root and topsoil in alpine meadow of the north- eastern Qinghai-Tibet Plateau
}

\begin{abstract}
Wen $\mathrm{Li}^{1}$, Jinlan Wang ${ }^{1}$, Xiaolong $\mathrm{Li}^{1}$, Shilin Wang ${ }^{1}$, Wenhui Liu ${ }^{2}$, Shangli Shi ${ }^{1}$ \& Wenxia Cao ${ }^{1}$
Soil respiration (Rs) plays a critical role in the global carbon (C) balance, especially in the context of globally increasing nitrogen $(\mathrm{N})$ deposition. However, how $\mathrm{N}$-addition influences $\mathrm{C}$ cycle remains unclear. Here, we applied seven levels of N application (0 (N0), 54 (N1), 90 (N2), 126 (N3), 144 (N4), 180 (N5) and $216 \mathrm{~kg} \mathrm{~N} \mathrm{ha}^{-1} \mathrm{yr}^{-1}$ (N6)) to quantify their impacts on Rs and its components (autotrophic respiration ( $\mathrm{Ra}$ ) and heterotrophic respiration ( $\mathrm{Rh})$ ) and $\mathrm{C}$ and $\mathrm{N}$ storage in vegetation and soil in alpine meadow on the northeast margin of the Qinghai-Tibetan Plateau. We used a structural equation model (SEM) to explore the relative contributions of $\mathrm{C}$ and $\mathrm{N}$ storage, soil temperature and soil moisture and their direct and indirect pathways in regulating soil respiration. Our results revealed that the $\mathrm{Rs}, \mathrm{Ra}$ and $\mathrm{Rh}, \mathrm{C}$ and $\mathrm{N}$ storage in plant, root and soil $(0-10 \mathrm{~cm}$ and $10-20 \mathrm{~cm})$ all showed initial increases and then tended to decrease at the threshold level of $180 \mathrm{~kg} \mathrm{~N} \mathrm{ha}^{-1} \mathrm{yr}^{-1}$. The SEM results indicated that soil temperature had a greater impact on Rs than did volumetric soil moisture. Moreover, SEM also showed that $C$ storage (in root, $0-10$ and $10-20 \mathrm{~cm}$ soil layers) was the most important factor driving Rs. Furthermore, multiple linear regression model showed that the combined root $C$ storage, $0-10 \mathrm{~cm}$ and 10-20 cm soil layer C storage explained $97.4-97.6 \%$ variations in Rs; explained $94.5-96 \%$ variations in $\mathrm{Ra}$; and explained $96.3-98.1 \%$ in $\mathrm{Rh}$. Therefore, the growing season soil respiration and its components can be well predicted by the organic $C$ storage in root and topsoil in alpine meadow of the north-eastern Qinghai-Tibetan Plateau. Our study reveals the importance of topsoil and root $C$ storage in driving growing season Rs in alpine meadow on the northeast margin of Qinghai-Tibetan Plateau.
\end{abstract}

Human activities such as agricultural expansion, industrial development and deforestation have enormously altered the rate of $\mathrm{N}$ deposition ${ }^{1,2}$. Terrestrial ecosystems have been experiencing approximately twice the input of $\mathrm{N}$ worldwide compared to the level of the pre-industrial era ${ }^{2}$. According to the results of Lamarque et al. ${ }^{3}, \mathrm{~N}$ deposition in the global terrestrial ecosystems will range from 60 to $100 \mathrm{Tg}(\mathrm{N})$ per year by 2100 . Moreover, the rate of $\mathrm{N}$ deposition will increase 2.5-fold in the next century ${ }^{4}$. Excess $\mathrm{N}$ has caused a range of ecological problems such as a reduction of biological diversity, affecting net primary productivity, community structure and alterations to the $\mathrm{C} \mathrm{cycle}^{5,6}$. One of the main scientific problems to be addressed is to determine how $\mathrm{N}$ deposition influences $\mathrm{C}$ cycle $^{7,8}$. Grasslands serve as a very important $\mathrm{C}$ pool. They store approximately $34 \%$ of the terrestrial global C stock ${ }^{9}$. Soil respiration (Rs) is an important source of C efflux from soil surface to atmosphere ${ }^{10}$. A small change in Rs can alter the concentration of $\mathrm{CO}_{2}$ in the atmosphere ${ }^{11,12}$. Therefore, understanding the magnitude of $\mathrm{CO}_{2}$ fluxes emitted from grassland and grassland $\mathrm{C}$ pool are crucial to estimate the contribution of grassland ecosystems to the global C budget ${ }^{13}$. Although there have been a lot of studies about the effects of $\mathrm{N}$ deposition on Rs, the results remain controversial. For example, Wang et al. ${ }^{14}$ reported that $\mathrm{N}$ addition increased the Rs

${ }^{1}$ Grassland Ecosystem Key Laboratory of Ministry of Education, Sino-U.S. Research Centers for Sustainable Grassland and Livestock Management, Grassland Science College of Gansu Agricultural University, Lanzhou, 730070, People's Republic of China. 'Grassland Institute, Qinghai Academy of Animal Science and Veterinary Medicine, Xining, 810003, People's Republic of China. Correspondence and requests for materials should be addressed to S.S. (email: shishl@gsau.edu.cn) orW.C. (email: caowenxia@foxmail.com) 
due to the enhanced C availability on Chinese Loess Plateau. However, Janssens et al. ${ }^{15}$ reported that $\mathrm{N}$ might be limiting microbial growth and thus decreased Rs. Furthermore, Eberwein et al. ${ }^{16}$ observed that $\mathrm{N}$ addition increased Rs when $\mathrm{C}$ was abundant, while decrease Rs when $\mathrm{C}$ was limited. The inconsistency of these results might reflect study differences in ecosystem type, nutrient limitation and the rate of $\mathrm{N}$ addition ${ }^{17,18}$. In addition, the difference in results is partly owing to Rs which is a multisource flux, usually partitioned into the autotrophic respiration $(\mathrm{Ra})$ and heterotrophic respiration $(\mathrm{Rh})^{19}$. Generally, $\mathrm{Ra}$ is the sum of root and rhizosphere microbial respiration, which is driven by belowground $\mathrm{C}$ allocation ${ }^{20}$. Rh is derived from the decomposition of litter and organic matter, which is affected by the microbial activity and substrate concentration ${ }^{20} . \mathrm{N}$ fertilizer may improve Ra by promoting plant growth. Meanwhile, $\mathrm{N}$ fertilizer may suppress Ra through reduce photosynthesis allocated belowground ${ }^{19}$. Similarly, $\mathrm{N}$ fertilizer may improve Rh by enhancing soil microbial biomass and microbial activity or suppress it through reduce enzyme activity and decomposition of soil organic matter ${ }^{19}$. In addition, soil temperature, soil moisture content ${ }^{21,22}$, and $\mathrm{C}$ and $\mathrm{N}$ pools ${ }^{23,24}$ are also important factors that regulate Rs by regulating respiratory enzyme activity and substrate supplies. However, it is still unclear how these variables directly or indirectly control autotrophic and heterotrophic respiration. Therefore, further studies should be conducted to understand the main factors driving $\mathrm{Ra}$ and $\mathrm{Rh}$ for further $\mathrm{C}$ balance management.

Previous studies about $\mathrm{N}$ fertilizer on soil respiration have been conducted in various ecosystems ${ }^{16,18,19,25,26}$. However, the results of $\mathrm{N}$-addition on respiration components were not consistent. For example, a study conducted in a Tibetan alpine steppe showed that $\mathrm{N}$ enrichment increased Rs and Ra but decreased $\mathrm{Rh}^{26}$. Zhang et al. ${ }^{25}$ showed that the growing season Rs, Ra and Rh were significantly increased in high N-addition treatment $(92 \mathrm{~kg} \mathrm{~N}$ $\mathrm{ha}^{-2} \mathrm{y}^{-1}$ ) in semiarid grassland. Chen et al. ${ }^{19}$ reported that $\mathrm{N}$ supply significantly increased the Rs and $\mathrm{Ra}$, but had no effects on $\mathrm{Rh}$ in a rain fed cropland ecosystem. However, a study conducted by Olsson et al. ${ }^{27}$ showed that $\mathrm{N}$ fertilizer decreased Rs and $\mathrm{Ra}$ in a forest ecosystem. Therefore, further study about the responses of Ra and $\mathrm{Rh}$ to $\mathrm{N}$ supply is vital in accurately predicting future global $\mathrm{C}$ balance.

$\mathrm{N}$ deposition and rising atmospheric carbon dioxide content are two main mechanisms underlying terrestrial ecosystems $\mathrm{C}$ sequestration ${ }^{28}$. Therefore, quantifying the magnitude of Rs and $\mathrm{C}$ storage in response to different levels of $\mathrm{N}$ application in grassland ecosystem can help build a model projection of future climate change. However, how the increasing $\mathrm{N}$ deposition influences $\mathrm{C}$ cycles remains unclear ${ }^{29,30}$. In addition, it remains unclear how $\mathrm{N}$ addition influences Rs and, more specifically, how $\mathrm{N}$ deposition influences Rs by affecting $\mathrm{C}$ storage. Given the above issues, in this research, we conducted a three-year field experiment that simulated atmospheric $\mathrm{N}$ deposition in alpine meadow region on the northeast margin of Qinghai-Tibetan Plateau to elucidate the impacts of $\mathrm{N}$ deposition on $\mathrm{Ra}, \mathrm{Rh}$ and $\mathrm{Rs}, \mathrm{C}$ and $\mathrm{N}$ storage. The purpose of our study was: (1) to identify the response of Rs and its components to various gradients of $\mathrm{N}$ addition, (2) to investigate the responses of vegetation and soil $\mathrm{C}$ and $\mathrm{N}$ storage to various gradients of $\mathrm{N}$ addition, (3) to explore the mechanisms by which $\mathrm{N}$ deposition influences Rs by affecting $\mathrm{C}$ and $\mathrm{N}$ storage. The ultimate goal of this research was to explore the underlying responses of ecosystem $\mathrm{C}$ storage and $\mathrm{CO}_{2}$ fluxes to $\mathrm{N}$ addition.

\section{Results}

Biotic and abiotic variables. During the two experimental years, the above- and below-ground biomass were higher in the $\mathrm{N}$-addition treatments than N0 treatment. Meanwhile, the above- and below-ground biomass showed an increasing trend with increasing amounts of $\mathrm{N}$ addition up to the N5 treatment, and then decreased in the N6 treatment (Table 1). N application had no significant impact on litter biomass and soil bulk density in 0-10, 10-20 and 20-30 cm soil layer during the two experimental years. In 2014 and 2015, the soil temperature at $5 \mathrm{~cm}$ depth (ST5), soil moisture content at $10 \mathrm{~cm}$ depth and (SM10) soil microbial biomass carbon (SMBC), soil organic carbon (SOC) and soil total nitrogen (TN) contents were significantly increased in the N3, N4, N5 and N6 treatments relative to N0 treatment.

Soil respiration and its components. During the two experimental years, the Ra, Rh and Rs showed similar seasonal variation among the various $\mathrm{N}$-addition treatments, with the higher values found in August and lower values found in October (Fig. 1). Meanwhile, during the growing seasons (May - October), the Ra, $\mathrm{Rh}$ and Rs showed an increasing trend with increasing amounts of $\mathrm{N}$-addition up to the N5 treatment, and then decreased in the N6 treatment. The growing seasons mean Ra, Rh and Rs were significantly increased in the N3, N4, N5 and N6 treatments in both experimental years compared to the N0 treatment (Fig. 1).

Carbon and nitrogen storage. The $\mathrm{C}$ storage showed an increasing trend in plant and root with increasing amounts of $\mathrm{N}$ addition up to the $\mathrm{N} 5$ treatment, and then decreased in the N6 treatment. However, $\mathrm{N}$ addition had no impact on litter $\mathrm{C}$ or $\mathrm{N}$ storage. The vegetation $\mathrm{C}$ storage was significantly increased in the $\mathrm{N}$ application treatments compared to the N0 treatment in 2014 and 2015. N storage in plant, litter and root showed similar trends to those of $\mathrm{C}$ storage. At $0-10$ and $10-20 \mathrm{~cm}$ soil layer, SOC storage and total $\mathrm{N}$ storage differed significantly in the different $\mathrm{N}$-addition treatments, whereas in deeper soil, $\mathrm{N}$ application had no significant impact on SOC or $\mathrm{N}$ storage (Figs 2 and 3). The SOC storage in the $0-30 \mathrm{~cm}$ soil layer was significantly increased in the N3, N4, N5 and $\mathrm{N} 6$ treatments in both experimental years (Fig. 2). While the soil total $\mathrm{N}$ storage in the $0-30 \mathrm{~cm}$ soil layer was significantly increased in the N2, N3, N4, N5 and N6 treatments in both experimental years. The ecosystem C and $\mathrm{N}$ storage all showed an increasing trend with increasing amounts of $\mathrm{N}$-addition up to the $\mathrm{N} 5$ treatment, and then decreased in the N6 treatment (Figs 2 and 3). Ecosystem C storage and N storage were significantly increased in all of the $\mathrm{N}$-addition treatments except the N1 treatment in both experimental years.

Soil respiration and its components in relation to carbon and nitrogen storage. A principal component analysis (PCA) was used to determine the correlations among the $\mathrm{C}$ and $\mathrm{N}$ storage in plant, litter and soil (Fig. 4). The results showed that the first, second, and third axes explained $64.17 \%, 12.24 \%$ and $9.57 \%$ of the 


\begin{tabular}{|c|c|c|c|c|c|c|c|c|}
\hline \multirow[b]{2}{*}{ Variable } & \multirow[b]{2}{*}{ Year } & \multicolumn{7}{|c|}{ Nitrogen addition treatments } \\
\hline & & No & N1 & N2 & N3 & N4 & N5 & N6 \\
\hline \multirow{2}{*}{$\mathrm{ABG}\left(\mathrm{g} \bullet \mathrm{m}^{-2}\right)$} & 2014 & $380.47 \pm 12.65 \mathrm{e}$ & $468.54 \pm 17.81 \mathrm{~d}$ & $529.33 \pm 14.55 c$ & $576.40 \pm 13.28 \mathrm{~b}$ & $623.65 \pm 16.74 \mathrm{a}$ & $647.28 \pm 17.89 a$ & $544.40 \pm 10.42 \mathrm{bc}$ \\
\hline & 2015 & $349.95 \pm 17.85 \mathrm{f}$ & $458.22 \pm 26.22 \mathrm{e}$ & $521.23 \pm 12.56 \mathrm{~d}$ & $596.87 \pm 15.55 c$ & $687.57 \pm 18.24 \mathrm{~b}$ & $782.29 \pm 17.14 \mathrm{a}$ & $709.37 \pm 18.25 b$ \\
\hline \multirow{2}{*}{$\mathrm{BGB}\left(\mathrm{g} \bullet \mathrm{m}^{-2}\right)$} & 2014 & $3411.06 \pm 138.56 c$ & $4377.60 \pm 115.43 \mathrm{~b}$ & $4519.88 \pm 99.78 b$ & $5289.64 \pm 115.47 \mathrm{a}$ & $5617.37 \pm 196.33 a$ & $5568.58 \pm 190.75 a$ & $4577.19 \pm 173.21 \mathrm{~b}$ \\
\hline & 2015 & $3257.14 \pm 138.25 \mathrm{~d}$ & $3586.74 \pm 167.65 \mathrm{~cd}$ & $3924.6 \pm 201.55 \mathrm{c}$ & $4659.88 \pm 201.57 b$ & $5351.58 \pm 187.52 \mathrm{a}$ & $5624.97 \pm 284.55 \mathrm{a}$ & $4837.19 \pm 188.56 \mathrm{~b}$ \\
\hline \multirow{2}{*}{$\mathrm{LB}\left(\mathrm{g} \bullet \mathrm{m}^{-2}\right)$} & 2014 & $33.17 \pm 2.89 \mathrm{a}$ & $32.46 \pm 3.46 \mathrm{a}$ & $33.22 \pm 2.91 \mathrm{a}$ & $33.28 \pm 2.31 \mathrm{a}$ & $34.02 \pm 2.31 \mathrm{a}$ & $33.23 \pm 3.46 \mathrm{a}$ & $32.33 \pm 0.88 \mathrm{a}$ \\
\hline & 2015 & $34.48 \pm 2.31 \mathrm{a}$ & $33.97 \pm 1.73 a$ & $33.78 \pm 1.73 a$ & $35.16 \pm 2.89 \mathrm{a}$ & $34.96 \pm 2.31 \mathrm{a}$ & $35.33 \pm 0.88 \mathrm{a}$ & $35.07 \pm 2.89 \mathrm{a}$ \\
\hline \multirow{2}{*}{$\begin{array}{l}\text { Shannon-Wiener } \\
\text { diversity index }\end{array}$} & 2014 & $2.52 \pm 0.03 \mathrm{a}$ & $2.53 \pm 0.04 \mathrm{a}$ & $2.46 \pm 0.02 \mathrm{a}$ & $2.21 \pm 0.03 \mathrm{abc}$ & $1.88 \pm 0.02 \mathrm{c}$ & $2.18 \pm 0.02 b$ & $2.24 \pm 0.03 \mathrm{ab}$ \\
\hline & 2015 & $2.48 \pm 0.03 \mathrm{a}$ & $2.45 \pm 0.03 a$ & $2.41 \pm 0.02 \mathrm{a}$ & $2.26 \pm 0.03 \mathrm{ab}$ & $2.05 \pm 0.03 b c$ & $1.76 \pm 0.02 \mathrm{c}$ & $1.84 \pm 0.02 \mathrm{c}$ \\
\hline \multirow{2}{*}{ Pielou evenness index } & 2014 & $0.97 \pm 0.01 \mathrm{a}$ & $0.96 \pm 0.01 \mathrm{a}$ & $0.89 \pm 0.01 \mathrm{ab}$ & $0.87 \pm 0.01 \mathrm{ab}$ & $0.84 \pm 0.01 \mathrm{ab}$ & $0.80 \pm 0.01 \mathrm{~b}$ & $0.84 \pm 0.01 \mathrm{ab}$ \\
\hline & 2015 & $0.95 \pm 0.02 \mathrm{a}$ & $0.91 \pm 0.01 \mathrm{ab}$ & $0.86 \pm 0.01 \mathrm{ab}$ & $0.82 \pm 0.01 \mathrm{ab}$ & $0.77 \pm 0.01 \mathrm{ab}$ & $0.71 \pm 0.01 \mathrm{~b}$ & $0.76 \pm 0.01 \mathrm{ab}$ \\
\hline \multirow{2}{*}{ Richness index } & 2014 & $14.00 \pm 0.00 \mathrm{a}$ & $14.00 \pm 0.00 \mathrm{a}$ & $13.67 \pm 0.33 a$ & $13.00 \pm 0.00 \mathrm{a}$ & $12.67 \pm 0.54 \mathrm{a}$ & $12.67 \pm 0.69 \mathrm{a}$ & $12.67 \pm 0.53 a$ \\
\hline & 2015 & $13.67 \pm 0.76 \mathrm{a}$ & $13.33 \pm 0.46 a$ & $13.33 \pm 0.52 a$ & $13.00 \pm 0.00 \mathrm{a}$ & $12.67 \pm 0.49 \mathrm{a}$ & $12.33 \pm 0.38 \mathrm{a}$ & $12.67 \pm 0.49 \mathrm{a}$ \\
\hline \multirow{2}{*}{ ST5 $\left({ }^{\circ} \mathrm{C}\right)$} & 2014 & $10.73 \pm 0.22 \mathrm{a}$ & $10.69 \pm 0.24 \mathrm{a}$ & $10.71 \pm 0.24 \mathrm{a}$ & $10.29 \pm 0.21 \mathrm{~b}$ & $10.17 \pm 0.2 \mathrm{~b}$ & $9.97 \pm 0.19 \mathrm{~b}$ & $10.11 \pm 0.2 \mathrm{~b}$ \\
\hline & \begin{tabular}{|l|}
2015 \\
\end{tabular} & $10.86 \pm 0.19 a$ & $10.57 \pm 0.17 \mathrm{ab}$ & $10.31 \pm 0.16 \mathrm{~b}$ & $10.41 \pm 0.15 \mathrm{~b}$ & $10.23 \pm 0.12 b$ & $10.14 \pm 0.13 b$ & $10.13 \pm 0.13 b$ \\
\hline \multirow{2}{*}{ SM10 (\%) } & 2014 & $26.62 \pm 0.69 \mathrm{~b}$ & $26.82 \pm 0.71 \mathrm{~b}$ & $26.77 \pm 0.69 \mathrm{~b}$ & $27.15 \pm 0.68 \mathrm{a}$ & $27.13 \pm 0.68 \mathrm{a}$ & $27.19 \pm 0.68 \mathrm{a}$ & $27.09 \pm 0.7 \mathrm{a}$ \\
\hline & 2015 & $25.53 \pm 0.95 b$ & $25.61 \pm 0.93 \mathrm{~b}$ & $25.34 \pm 0.95 b$ & $25.67 \pm 0.95 \mathrm{~b}$ & $26.16 \pm 0.9 \mathrm{a}$ & $26.29 \pm 0.98 \mathrm{a}$ & $26.16 \pm 0.91 \mathrm{a}$ \\
\hline \multirow{2}{*}{ 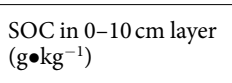 } & 2014 & $46.23 \pm 1.27 \mathrm{~d}$ & $46.67 \pm 0.3 \mathrm{~d}$ & $49.11 \pm 0.65 c$ & $50.37 \pm 0.35 b c$ & $51.82 \pm 0.51 \mathrm{~b}$ & $53.94 \pm 0.33 a$ & $49.69 \pm 0.51 \mathrm{c}$ \\
\hline & 2015 & $46.54 \pm 1.87 \mathrm{~d}$ & $46.98 \pm 0.62 \mathrm{~cd}$ & $47.18 \pm 0.19 \mathrm{~cd}$ & $49.48 \pm 0.2 b c$ & $51.24 \pm 0.51 \mathrm{~b}$ & $55.49 \pm 0.51 \mathrm{a}$ & $50.27 \pm 0.19 b$ \\
\hline \multirow{2}{*}{$\begin{array}{l}\text { SOC in } 10-20 \mathrm{~cm} \\
\text { layer }\left({\left.\mathrm{g} \bullet \mathrm{kg}^{-1}\right)}^{-1}\right.\end{array}$} & 2014 & $35.11 \pm 0.65 \mathrm{~b}$ & $34.92 \pm 0.54 \mathrm{~b}$ & $35.09 \pm 0.69 \mathrm{~b}$ & $36.60 \pm 0.55 b$ & $35.56 \pm 0.23 \mathrm{~b}$ & $39.33 \pm 0.56 \mathrm{a}$ & $38.98 \pm 0.64 \mathrm{a}$ \\
\hline & 2015 & $36.12 \pm 0.69 c$ & $36.19 \pm 0.97 \mathrm{c}$ & $34.65 \pm 0.11 \mathrm{c}$ & $36.16 \pm 0.34 c$ & $37.92 \pm 0.26 \mathrm{~b}$ & $40.8 \pm 0.51 \mathrm{a}$ & $38.82 \pm 0.49 \mathrm{~b}$ \\
\hline \multirow{2}{*}{$\begin{array}{l}\text { SOC in } 20-30 \mathrm{~cm} \\
\text { layer }\left({\left.\mathrm{g} \bullet \mathrm{kg}^{-1}\right)}^{-1}\right.\end{array}$} & 2014 & $25.68 \pm 0.05 \mathrm{a}$ & $25.46 \pm 0.29 \mathrm{a}$ & $25.56 \pm 0.32 \mathrm{a}$ & $24.86 \pm 0.29 \mathrm{a}$ & $26.24 \pm 1.03 a$ & $26.35 \pm 0.26 \mathrm{a}$ & $25.85 \pm 0.47 \mathrm{a}$ \\
\hline & 2015 & $26.39 \pm 0.88 \mathrm{a}$ & $26.80 \pm 0.39 \mathrm{a}$ & $25.02 \pm 0.6 \mathrm{a}$ & $25.68 \pm 0.88 \mathrm{a}$ & $24.94 \pm 0.44 \mathrm{a}$ & $26.10 \pm 0.33 a$ & $26.26 \pm 0.31 \mathrm{a}$ \\
\hline \multirow{2}{*}{$\begin{array}{l}\mathrm{TN} \text { in } 0-10 \mathrm{~cm} \text { layer } \\
\left(\mathrm{g} \bullet \mathrm{kg}^{-1}\right)\end{array}$} & 2014 & $4.20 \pm 0.01 \mathrm{e}$ & $4.19 \pm 0.01 \mathrm{e}$ & $4.33 \pm 0.02 \mathrm{~d}$ & $4.44 \pm 0.01 \mathrm{c}$ & $4.57 \pm 0.01 \mathrm{~b}$ & $4.72 \pm 0.03 \mathrm{a}$ & $4.53 \pm 0.03 \mathrm{~b}$ \\
\hline & 2015 & $4.24 \pm 0.03 \mathrm{e}$ & $4.22 \pm 0.01 \mathrm{e}$ & $4.36 \pm 0.02 \mathrm{~d}$ & $4.44 \pm 0.01 \mathrm{c}$ & $4.60 \pm 0.06 \mathrm{~b}$ & $4.80 \pm 0.01 \mathrm{a}$ & $4.60 \pm 0.01 \mathrm{~b}$ \\
\hline \multirow{2}{*}{ 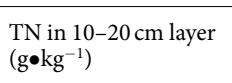 } & 2014 & $3.67 \pm 0.02 \mathrm{e}$ & $3.72 \pm 0.01 \mathrm{de}$ & $3.71 \pm 0.02 \mathrm{de}$ & $3.79 \pm 0.02 \mathrm{~cd}$ & $3.90 \pm 0.03 \mathrm{ab}$ & $3.95 \pm 0.05 \mathrm{a}$ & $3.85 \pm 0.02 \mathrm{bc}$ \\
\hline & 2015 & $3.71 \pm 0.04 \mathrm{e}$ & $3.69 \pm 0.01 \mathrm{e}$ & $3.71 \pm 0.02 \mathrm{e}$ & $3.81 \pm 0.01 \mathrm{~cd}$ & $3.89 \pm 0.02 \mathrm{~b}$ & $3.94 \pm 0.03 \mathrm{a}$ & $3.84 \pm 0.01 \mathrm{~b}$ \\
\hline \multirow{2}{*}{$\begin{array}{l}\mathrm{TN} \text { in } 20-30 \mathrm{~cm} \text { layer } \\
\left(\mathrm{g} \bullet \mathrm{kg}^{-1}\right)\end{array}$} & 2014 & $3.46 \pm 0.03 \mathrm{a}$ & $3.49 \pm 0.01 \mathrm{a}$ & $3.48 \pm 0.01 \mathrm{a}$ & $3.49 \pm 0.01 \mathrm{a}$ & $3.41 \pm 0.01 \mathrm{a}$ & $3.44 \pm 0.02 \mathrm{a}$ & $3.45 \pm 0.01 \mathrm{a}$ \\
\hline & 2015 & $3.45 \pm 0.01 \mathrm{a}$ & $3.43 \pm 0.01 \mathrm{a}$ & $3.47 \pm 0.01 \mathrm{a}$ & $3.46 \pm 0.01 \mathrm{a}$ & $3.43 \pm 0.01 \mathrm{a}$ & $3.45 \pm 0.02 \mathrm{a}$ & $3.47 \pm 0.01 \mathrm{a}$ \\
\hline \multirow{2}{*}{$\begin{array}{l}\mathrm{MBC} \text { in } 0-10 \mathrm{~cm} \text { layer } \\
\left(\mathrm{mg}^{\circ} \mathrm{kg}^{-1}\right)\end{array}$} & 2014 & $399.43 \pm 10.77 \mathrm{c}$ & $406.05 \pm 9.5 c$ & $403.84 \pm 8.61 \mathrm{c}$ & $436.25 \pm 11.91 \mathrm{~b}$ & $433.57 \pm 7.36 \mathrm{~b}$ & $468.99 \pm 9.52 \mathrm{a}$ & $423.46 \pm 9.36 \mathrm{bc}$ \\
\hline & 2015 & $379.53 \pm 9.03 \mathrm{~d}$ & $393.07 \pm 7.28 \mathrm{~cd}$ & $393.43 \pm 7.0 \mathrm{~cd}$ & $414.88 \pm 9.6 \mathrm{bc}$ & $426.55 \pm 11.53 b$ & $456.81 \pm 9.2 \mathrm{a}$ & $431.93 \pm 12.16 \mathrm{~b}$ \\
\hline \multirow{2}{*}{ 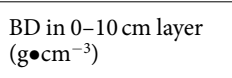 } & 2014 & $0.73 \pm 0.03 a$ & $0.76 \pm 0.04 \mathrm{a}$ & $0.74 \pm 0.04 \mathrm{a}$ & $0.75 \pm 0.07 \mathrm{a}$ & $0.76 \pm 0.05 \mathrm{a}$ & $0.75 \pm 0.07 \mathrm{a}$ & $0.76 \pm 0.1 \mathrm{a}$ \\
\hline & 2015 & $0.72 \pm 0.02 \mathrm{a}$ & $0.73 \pm 0.03 a$ & $0.72 \pm 0.03 \mathrm{a}$ & $0.72 \pm 0.06 \mathrm{a}$ & $0.73 \pm 0.03 \mathrm{a}$ & $0.71 \pm 0.02 \mathrm{a}$ & $0.71 \pm 0.01 \mathrm{a}$ \\
\hline \multirow{2}{*}{$\begin{array}{l}\text { BD in 10-20 cm layer } \\
\left(\mathrm{g} \bullet \mathrm{cm}^{-3}\right)\end{array}$} & 2014 & $0.80 \pm 0.03 \mathrm{a}$ & $0.81 \pm 0.03 \mathrm{a}$ & $0.81 \pm 0.02 \mathrm{a}$ & $0.80 \pm 0.05 a$ & $0.81 \pm 0.02 \mathrm{a}$ & $0.79 \pm 0.01 \mathrm{a}$ & $0.80 \pm 0.01 \mathrm{a}$ \\
\hline & 2015 & $0.80 \pm 0.02 \mathrm{a}$ & $0.81 \pm 0.03 \mathrm{a}$ & $0.80 \pm 0.03 a$ & $0.81 \pm 0.03 \mathrm{a}$ & $0.81 \pm 0.04 \mathrm{a}$ & $0.81 \pm 0.04 \mathrm{a}$ & $0.80 \pm 0.02 \mathrm{a}$ \\
\hline \multirow{2}{*}{$\begin{array}{l}\mathrm{BD} \text { in } 20-30 \mathrm{~cm} \text { layer } \\
\left(\mathrm{g} \bullet \mathrm{cm}^{-3}\right)\end{array}$} & 2014 & $0.82 \pm 0.03 \mathrm{a}$ & $0.82 \pm 0.03 \mathrm{a}$ & $0.82 \pm 0.02 \mathrm{a}$ & $0.82 \pm 0.04 \mathrm{a}$ & $0.82 \pm 0.04 \mathrm{a}$ & $0.83 \pm 0.01 \mathrm{a}$ & $0.83 \pm 0.02 \mathrm{a}$ \\
\hline & 2015 & $0.84 \pm 0.03 \mathrm{a}$ & $0.85 \pm 0.03 a$ & $0.84 \pm 0.03 a$ & $0.83 \pm 0.05 a$ & $0.84 \pm 0.06 \mathrm{a}$ & $0.84 \pm 0.02 \mathrm{a}$ & $0.86 \pm 0.02 \mathrm{a}$ \\
\hline
\end{tabular}

Table 1. The biotic and abiotic variables after 2 and 3 years of nitrogen-addition ( 2014 and 2015, respectively) in an alpine meadow ecosystem on the northeast margin of the Qinghai-Tibetan Plateau. Note: N0, N1, N2, N3, N4, N5 and N6 represent 0, 54, 90, 126, 144, 180 and $216 \mathrm{~kg} \mathrm{~N} \mathrm{ha}^{-1} \mathrm{yr}^{-1}$, respectively. Data are showed as the means \pm standard error. Different letters in the same row indicate significant differences at $P<0.05$. The belowground biomass was calculated for the $0-30 \mathrm{~cm}$ depth. ABG: Aboveground biomass; BGB: Belowground biomass; LB:Litter biomass; MBC: Microbial biomass carbon; SM10: Volumetric soil moisture content at $10 \mathrm{~cm}$ depth; ST5: Soil temperature at $5 \mathrm{~cm}$ depth; SOC: Soil organic carbon; TN: Soil total nitrogen; BD: Soil bulk density.

standardized variance, respectively. The highly weighted parameters (loading value $>0.900$ ) on PC1 were soil C storage in the $0-10 \mathrm{~cm}$ layer, soil $\mathrm{N}$ storage in the $0-10$ and $10-20 \mathrm{~cm}$ layers, and root $\mathrm{C}$ and $\mathrm{N}$ storage. The highly loaded parameter for PC3 was soil C storage in the $10-20 \mathrm{~cm}$ layer.

We chose the parameters with loading value greater than 0.900 in the PCA results, ST5 and SM10 as predictors to establish structural equation modelling (SEM) to explore the impact of $\mathrm{C}$ and $\mathrm{N}$ storage, soil temperature and soil moisture content on growing season Rs (Fig. 5). The results explained the changes in Rs well (goodness of fit index was $0.752 ; \chi^{2}=7.99$ and $P=0.18$ ). The results showed that $C$ storage had significant effect on growing season Rs $(P<0.05)$. While $\mathrm{N}$ storage, soil temperature and soil moisture had no significant effects on growing season Rs $(P>0.05)$. Simultaneously, the path coefficient of ST5 on Rs $(0.42)$ was higher than the path coefficient of SM10 on Rs (0.36). Therefore, we concluded that C storage (in root, the $0-10$ and $10-20 \mathrm{~cm}$ soil depths) is the most predominant variable controlling growing season soil respiration. Meanwhile, ST5 has a stronger effect than SM10 on soil respiration. Rs, $\mathrm{Ra}$ and $\mathrm{Rh}$ had positive linear relationships with root $\mathrm{C}$ storage, $0-10 \mathrm{~cm}$ soil 


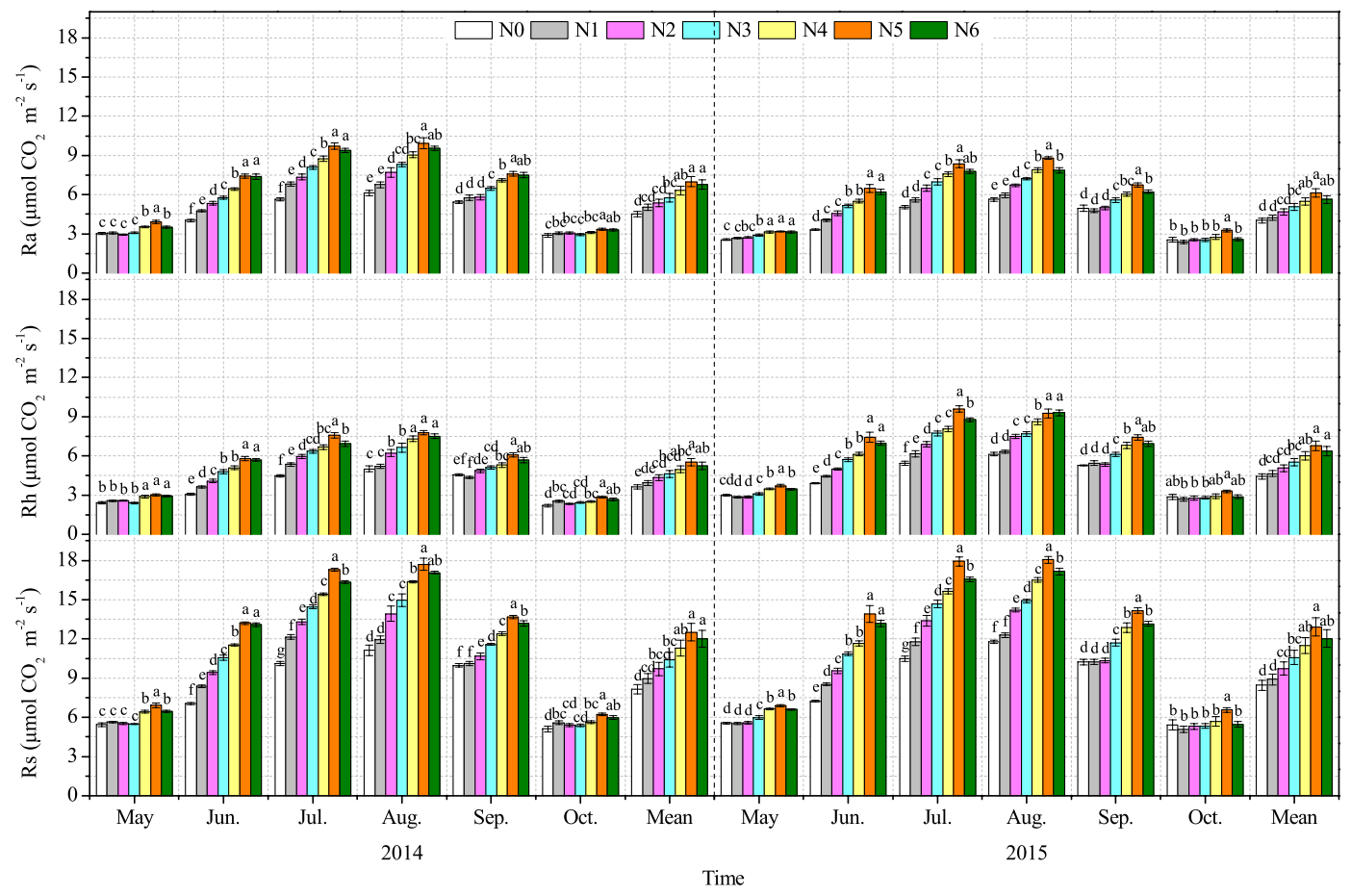

Figure 1. Seasonal variation in autotrophic respiration $(\mathrm{Ra})$, heterotrophic respiration $(\mathrm{Rh})$ and soil respiration (Rs) in an alpine meadow under different nitrogen-addition treatments. N0, N1, N2, N3, N4, N5 and N6 represent $0,54,90,126,144,180$ and $216 \mathrm{~kg} \mathrm{~N} \mathrm{ha}^{-1} \mathrm{yr}^{-1}$, respectively. Mean: the average value of soil respiration from May to October. Different letters in the same month indicate significant differences at $P<0.05$. Twelve replications for Rs, $\mathrm{Ra}$ and $\mathrm{Rh}$ at each month, respectively.

layer C storage, 10-20 cm soil layer C storage (Fig. 6), soil temperature and soil moisture (Fig. 7). Multiple linear regression model showed that root carbon storage, soil organic carbon storage in $0-10 \mathrm{~cm}$ layer and soil organic carbon storage in 10-20 cm layer explained more than $94.5 \%$ of $\mathrm{Rs}, \mathrm{Ra}$ and $\mathrm{Rh}$ (Table 2 ).

\section{Discussion}

Soil respiration and its components. During the two experimental years, the growing season Rs was significantly increased in the $\mathrm{N}$-addition treatments, which suggests the stimulate effects of $\mathrm{N}$ fertilizer on Rs in alpine meadow ecosystem. Similar results were found in alpine steppe ${ }^{26}$ and semiarid grassland ecosystem ${ }^{25,30}$. Meanwhile, $\mathrm{N}$-addition significnatly stimulated the growing season $\mathrm{Ra}$ and $\mathrm{Rh}$ during the two experimental years. Therefore, we concluded that the stimulated effect of $\mathrm{N}$-addition on Rs was mainly due to the increase of $\mathrm{Rh}$ and $\mathrm{Ra}$ in alpine meadow on the northeastern Qinghai-Tibetan Plateau. The alpine meadow is an N limited grassland ecosystem and has strong capacity to immobilize external $\mathrm{N}^{31}$. Therefore, the above- and below-ground biomass was significantly increased after $\mathrm{N}$-addition. This can increase the supply of $\mathrm{C}$ substrates to support root and microbial internal stoichiometric requirements and thereby increase $\mathrm{Rh}^{32}$. Generally, root activity and biomass are major factors driving $\mathrm{Ra}^{33,34}$. Soil C concentration is an important regulator of $\mathrm{Rh}^{21}$. The $\mathrm{N}$-addition increases the soil $\mathrm{N}$ availability and thus promotes the plants growth in grassland ${ }^{31}$. The increased soil $\mathrm{N}$ content may meet the demand of soil microorganisms for $\mathrm{N}$ source, thus promoting microbial biomass and activity. Our study showed that the above- and below-ground biomass was significantly increased in the N2-N6 treatments relative to the N0 treatment (Table 1). Larger root biomass represents more root surface area and associated with higher $\mathrm{Ra}^{35}$. Therefore, the increased root biomass may improve the $\mathrm{Ra}$. Previous studies also indicated that $\mathrm{N}$-addition increased the root biomass and $\mathrm{Ra}^{25,36}$. However, a privious study conducted in a artificial forest showed that 8 years $\mathrm{N}$-addition had no impact on $\mathrm{Rs}^{37}$. They interpreted this due to a decrease in microbial biomass after $\mathrm{N}$-addition. Generally, $\mathrm{N}$ fertilizer could increase the $\mathrm{N}$ source for soil microorganism, and thus increased the microbial biomass and activity. In the current study, the microbial biomass carbon was significantly increased in N3-N5 treatments during the two experimental years (Table 1). The increased microbial biomass may improve the Rh and thereby increase Rs. Compared to the N5 treatment, the mean Rs in the N6 treatment was decreased by $4.0 \%$ and $6.9 \%$ in 2014 and 2015, respectively. In the current study, root biomass showed a similar hump-shape pattern response to Rs with increasing level of nitrogen addition (Table 1). Before the $\mathrm{N}$ saturation point $(180 \mathrm{~kg} \mathrm{~N}$ $\mathrm{ha}^{-1} \mathrm{yr}^{-1}$ ), root biomass increased, whereas after the saturation point, root biomass decreased. Meanwhile, the high-level $\mathrm{N}$ addition $\left(>180 \mathrm{~kg} \mathrm{~N} \mathrm{ha}^{-1} \mathrm{yr}^{-1}\right.$ ) can lead to soil acidification ${ }^{38}$, this in turn will accumulate poisonous substances and inhibit the activities of soil microorganisms ${ }^{39}$. Our research showed that the topsoil microbial biomass carbon in the N6 treatment was significnatly decreased by $9.7 \%$ and $5.4 \%$ in 2014 and 2015, compared to the N5 treatment. Thus, the decreased root biomass and microbial biomass carbon in the N6 site may decrease the root respiration and microbial respiration, and ultimately decrease the soil respiration. 


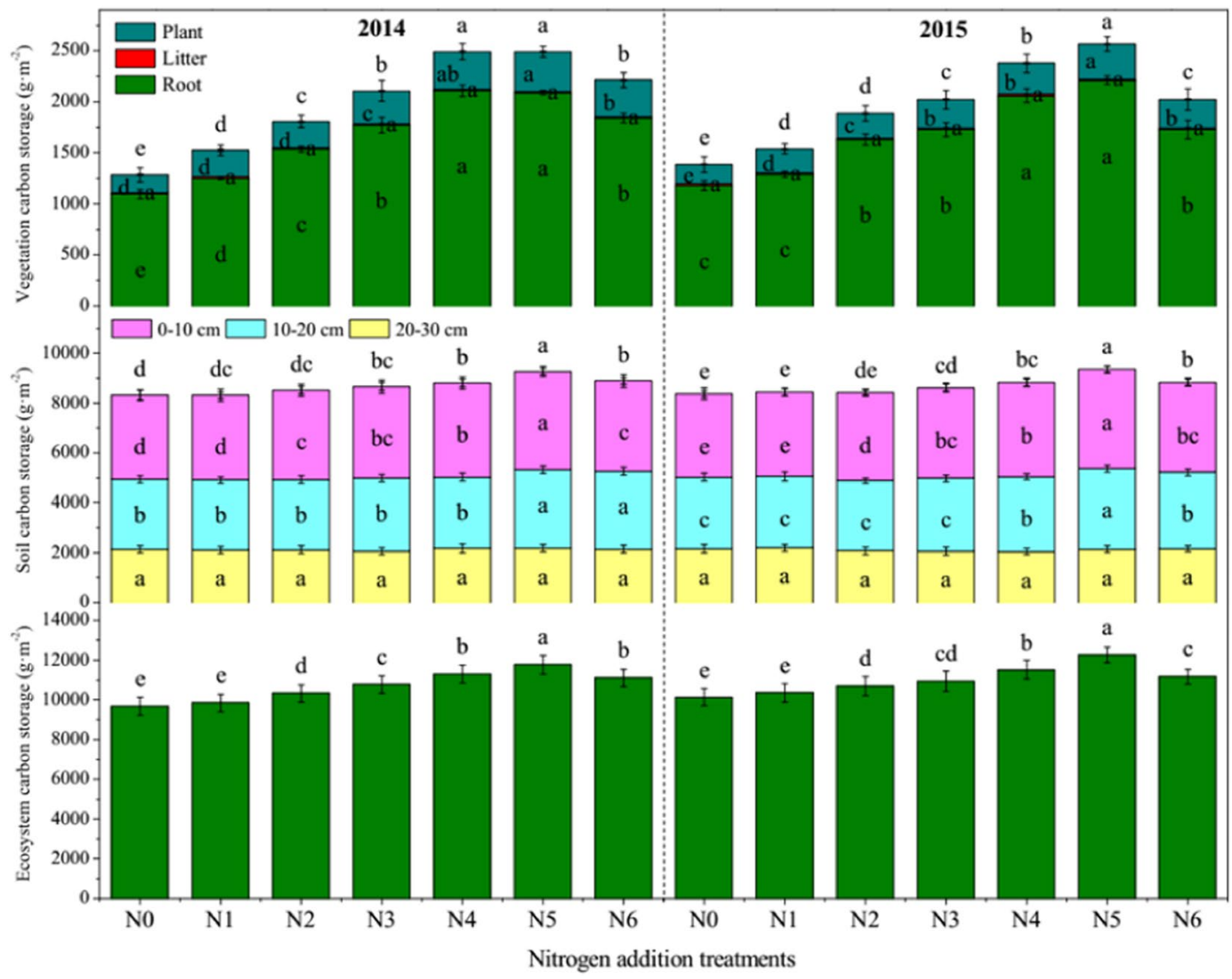

Figure 2. The organic carbon storage in vegetation, soil and ecosystem in an alpine meadow under different nitrogen addition treatments. N0, N1, N2, N3, N4, N5 and N6 represent 0, 54, 90, 126, 144, 180 and $216 \mathrm{~kg} \mathrm{~N}$ $\mathrm{ha}^{-1} \mathrm{yr}^{-1}$, respectively. Different letters indicate significant differences at $P<0.05$.

Carbon and nitrogen storage. $\mathrm{N}$-addition increased the content of soil available nitrogen, and thus stimulated the plant growth, and the plant $\mathrm{C}$ and $\mathrm{N}$ storage increased as a result. The experimental site was grazed in the cold season (November to May) by Tibetan sheep at a high livestock density (6.67-7.22 head per hectare). Almost all the above-ground biomass was removed by the herbivores until May of the next year. There was only little litter $\left(33-38 \mathrm{~g} / \mathrm{m}^{2}\right)$ in the experimental site. Meanwhile, there was no significant difference in litter biomass or litter $\mathrm{C}$ and $\mathrm{N}$ contents among the $\mathrm{N}$-addition treatments. Therefore, $\mathrm{N}$ application had no significant impact on litter $\mathrm{C}$ or $\mathrm{N}$ storage in current study. Previous researches about the effect of $\mathrm{N}$ enrichment on soil C storage were still highly controversial. For example, $\mathrm{N}$ addition significantly increased the $0-10 \mathrm{~cm}$ layer SOC storage in a Europe forest ecosystem $^{40}$. However, some studies reported that $\mathrm{N}$ application significantly decreased the SOC storage ${ }^{41,42}$. In these studies, $\mathrm{N}$ additions decreased the root biomass which led to little $\mathrm{C}$ allocation to belowground, and thus the SOC pool was decreased. In our study, the $\mathrm{C}$ storage in the $0-30 \mathrm{~cm}$ soil layer increased by $0.6-11.8 \%$ in $\mathrm{N}$-addition treatments. Wang et al. ${ }^{43}$ reported that the $0-40 \mathrm{~cm}$ layer SOC content increased by $34.7 \%$ after two years of $\mathrm{N}$ addition $\left(200 \mathrm{~kg} \mathrm{~N} \mathrm{ha}^{-1} \mathrm{yr}^{-1}\right)$ in an alpine meadow on the Qinghai-Tibetan Plateau. Dong et al. ${ }^{44}$ found that the SOC storage in $0-60 \mathrm{~cm}$ soil layer increased by $21.7 \%$ after 15 years of $\mathrm{N}$ addition $\left(200 \mathrm{~kg} \mathrm{~N} \mathrm{ha}^{-1} \mathrm{yr}^{-1}\right)$ in a farmland ecosystem of the North China Plain. Generally, SOC storage comes from photosynthetic carbon fixation. Plant root is crucial in controlling SOC pool through root decomposition and exudation. In our study, $\mathrm{N}$ addition caused a surge of dominant Elymus nutans, which have relatively greater abundance of leaf area. During the growing seasons, the plentiful sunlight makes the photosynthesis stronger in the $\mathrm{N}$ application treatments ${ }^{45}$. Therefore, $\mathrm{N}$ addition should stimulate root activity and increase root biomass ${ }^{46}$, thereby increasing soil $\mathrm{C}$ and $\mathrm{N}$ storage. In addition, the soil temperature difference between day and night is large in alpine meadow on the Qinghai-Tibetan Plateau ${ }^{47}$. The low temperature in the night may restrict the microbial and root activity that limited $\mathrm{Ra}$ and $\mathrm{Rh}^{48}$. Therefore, the high photosynthetic carbon fixation and low decomposition of organic matter made the higher SOC storage in the $\mathrm{N}$ application treatments in alpine meadow ecosystem on the Qinghai-Tibetan Plateau.

$\mathrm{N}$ addition influences the composition and structure of the vegetation community (Table 1) and thus influences ecosystem $\mathrm{C}$ and $\mathrm{N}$ storage ${ }^{49}$. Generally, $\mathrm{C}$ and $\mathrm{N}$ storage increased with increasing $\mathrm{N}$-addition rate in the current study. However, relative to the $\mathrm{N} 5$ level, the highest level of $\mathrm{N}$ addition $\left(216 \mathrm{~kg} \mathrm{~N} \mathrm{ha}^{-1} \mathrm{yr}^{-1}\right)$ decreased the vegetation, soil and ecosystem $\mathrm{C}$ and $\mathrm{N}$ storage. These results indicate that $\mathrm{C}$ and $\mathrm{N}$ storage appears to saturate at a high rate of $\mathrm{N}$ addition $\left(216 \mathrm{~kg} \mathrm{~N} \mathrm{ha}^{-1} \mathrm{yr}^{-1}\right)$ in excess of the $\mathrm{N}$ saturation point $\left(180 \mathrm{~kg} \mathrm{~N} \mathrm{ha}^{-1} \mathrm{yr}^{-1}\right)$. In cold region, temperature is the most important factor limiting plant growth ${ }^{36}$. Plants may have a threshold of nitrogen uptake in alpine meadow due to the low temperature, above which plant may not absorb more nitrogen even in high $\mathrm{N}$-addition treatment. Furthermore, the high rate of $\mathrm{N}$ addition can lead to soil acidification, which in turn 


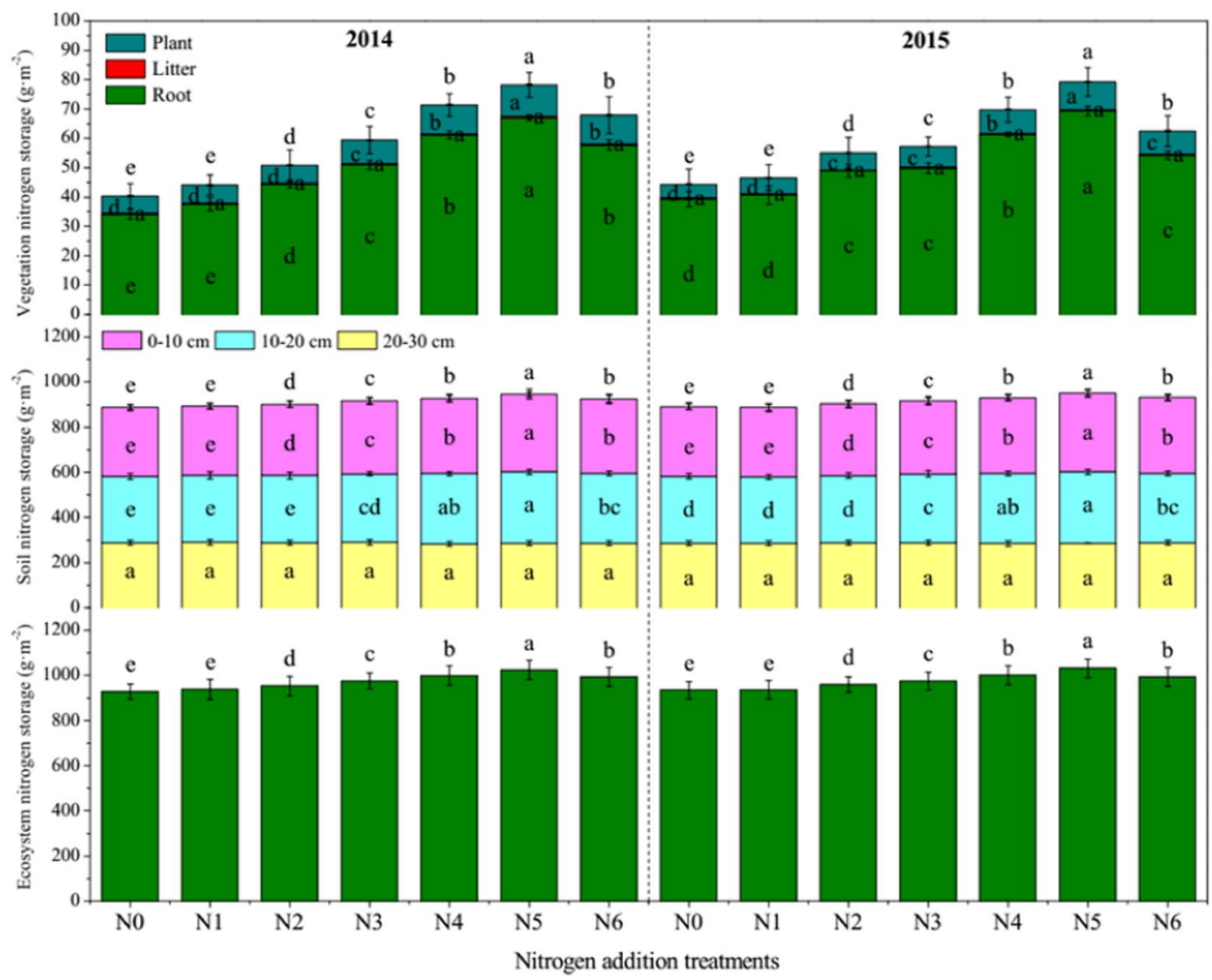

Figure 3. The total nitrogen storage in vegetation, soil and ecosystem in an alpine meadow under different nitrogen addition treatments. N0, N1, N2, N3, N4, N5 and N6 represent 0, 54, 90, 126, 144, 180 and $216 \mathrm{~kg} \mathrm{~N}$ $\mathrm{ha}^{-1} \mathrm{yr}^{-1}$, respectively. Different letters indicate significant differences at $P<0.05$.
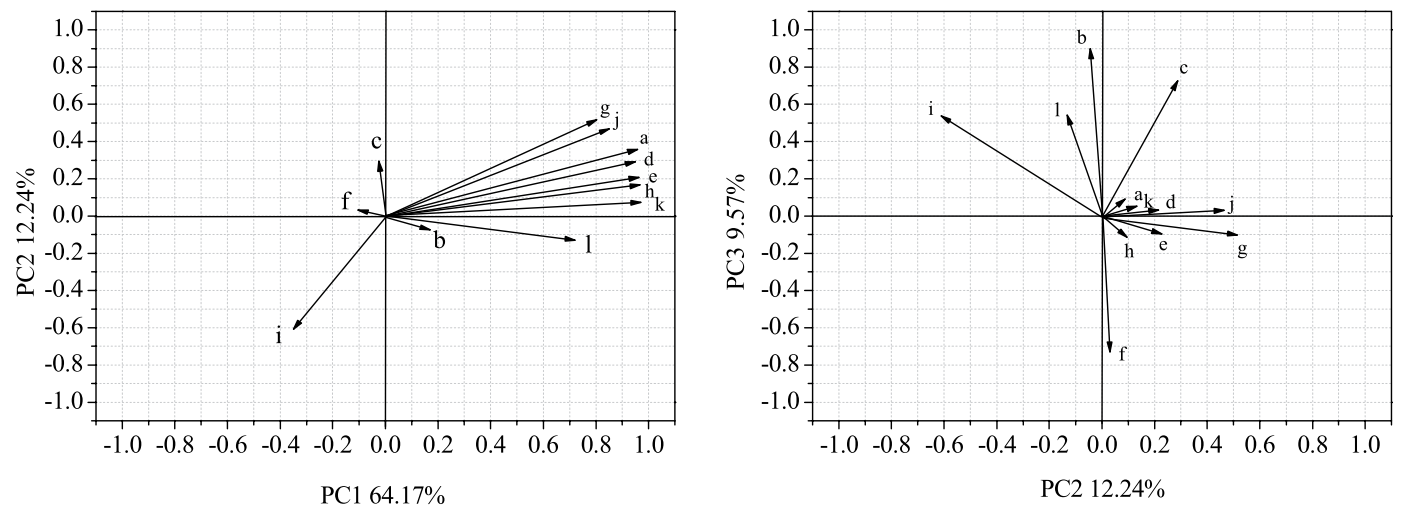

Figure 4. Principal component analysis of soil respiration as explained by carbon and nitrogen storage. a-soil organic carbon storage in the $0-10 \mathrm{~cm}$ soil layer, b-soil organic carbon storage in the $10-20 \mathrm{~cm}$ soil layer, c-soil organic carbon storage in the $20-30 \mathrm{~cm}$ soil layer, d-soil nitrogen storage in the $0-10 \mathrm{~cm}$ soil layer, e-soil nitrogen storage in the $10-20 \mathrm{~cm}$ soil layer, f-soil nitrogen storage in the $20-30 \mathrm{~cm}$ soil layer, g-plants carbon storage, h-root carbon storage in $0-30 \mathrm{~cm}$ soil layer, i-litter carbon storage, $\mathrm{j}$-plants nitrogen storage, $\mathrm{k}$-root nitrogen storage in $0-30 \mathrm{~cm}$ soil layer, l-litter nitrogen storage.

will limit plant and root growth, and thus decrease $\mathrm{C}$ and $\mathrm{N}$ storage in plant and $\operatorname{root}^{36,50,51}$. Our research also indecated that the above- and below-ground biomass in the N6 treatment were signifcantly decreased by $15.9 \%$ and $9.3 \%$, respectively, compared to the N5 treatment. The decomposition of dead root and litter is the main source of soil organic matter ${ }^{24}$. The decreased plant and root biomass in the N6 site may decrease the vegetation and soil $\mathrm{C}$ and $\mathrm{N}$ storage. Accordingly, high $\mathrm{N}$ addition beyond the $\mathrm{N}$ saturation point $\left(180 \mathrm{~kg} \mathrm{~N} \mathrm{ha}^{-1} \mathrm{yr}^{-1}\right)$ decreased vegetation, soil and ecosystem $\mathrm{C}$ and $\mathrm{N}$ storage. 


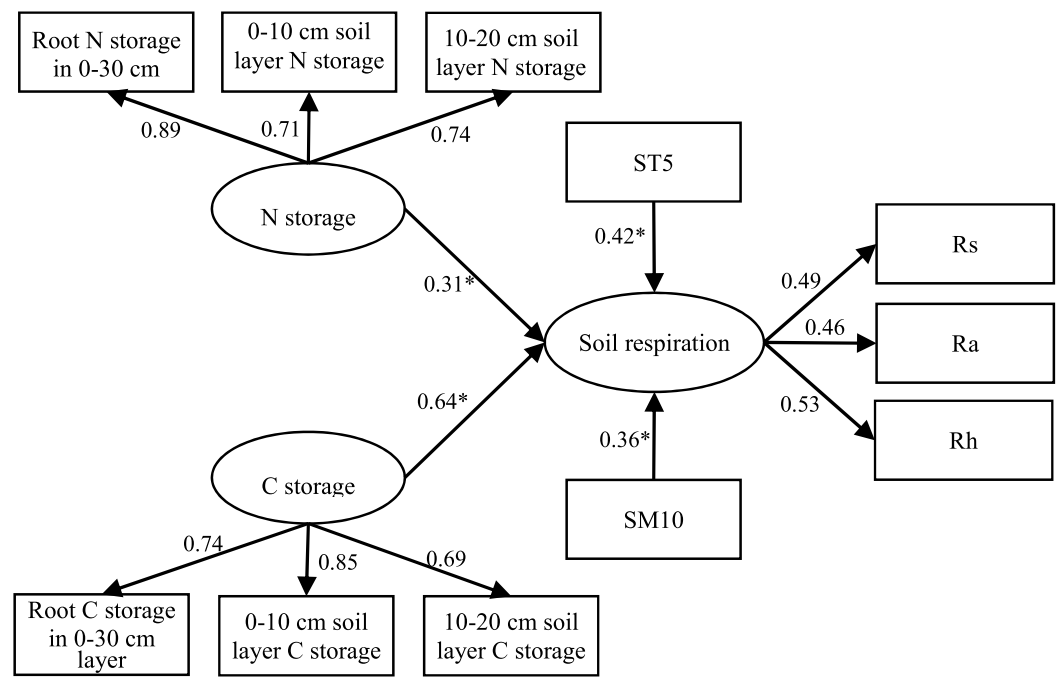

Figure 5. Structural equation model describing the influences of carbon and nitrogen storage, soil temperature at $5 \mathrm{~cm}$ depth and soil moisture content at $10 \mathrm{~cm}$ depth on growing season soil respiration and their relationships among each other. The rectangular boxes denote the observed variables, the ellipses denote latent variables. One-headed arrows indicate the relationships between variables. Numbers at arrows indicate standardized path coefficients or covariation coefficients. ST5: soil temperature at $5 \mathrm{~cm}$ depth; SM10: soil moisture content at $10 \mathrm{~cm}$ depth; Rs: total soil respiration; Ra: autotrophic respiration; Rh: heterotrophic respiration. *Indicates a significant difference at the 0.05 level.

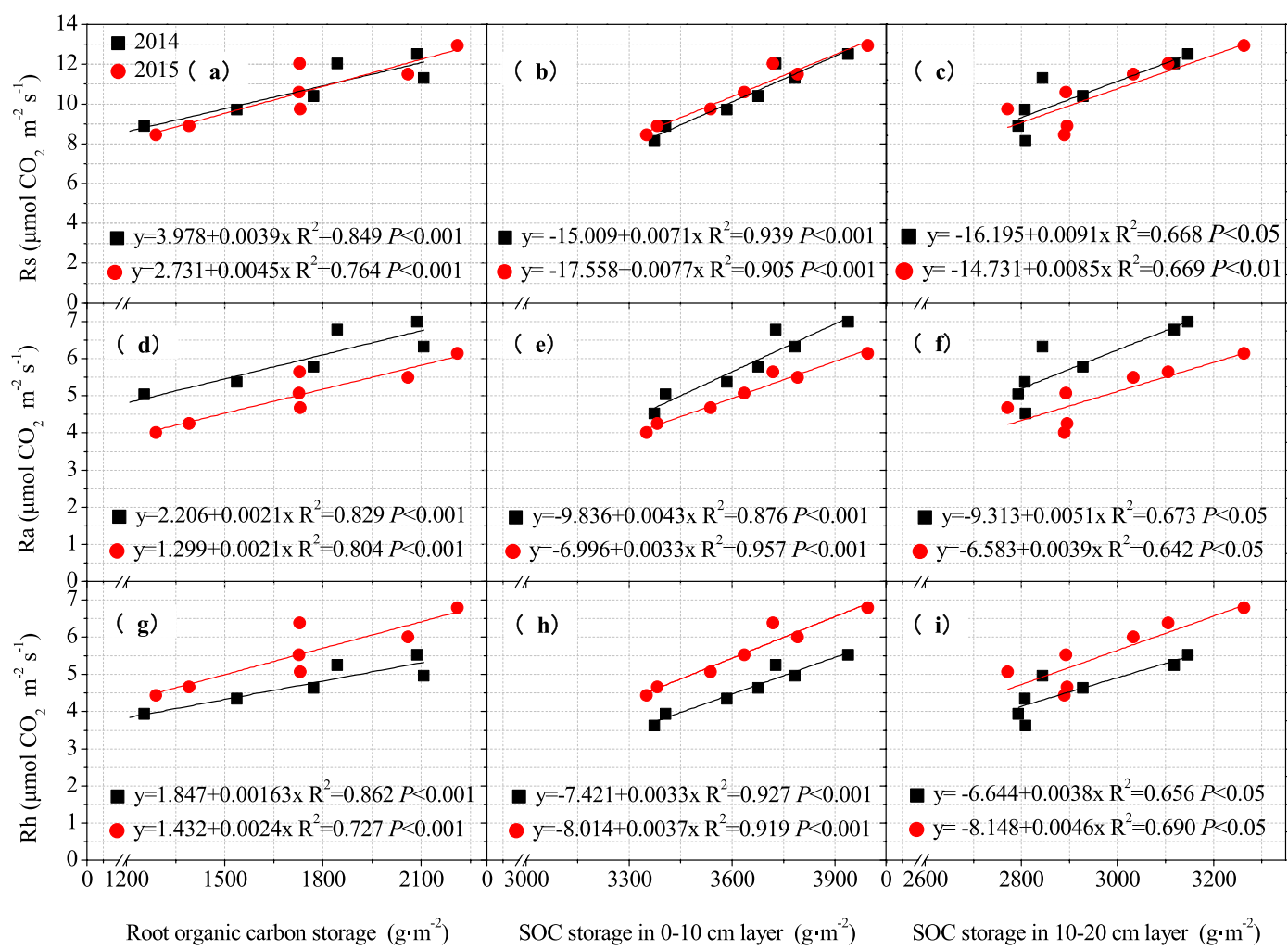

Figure 6. The relationships between soil respiration components (Rs, soil respiration; Ra, autotrophic respiration; $\mathrm{Rh}$, heterotrophic respiration) and organic carbon storage.

Correlations between soil respiration and its components and each of $\mathrm{C}$ and $\mathrm{N}$ storage. Previous researches about the factors driving Rs have mainly focused on ST, SM, plant, litter and below-ground biomass $^{52,53}$; and soil C and N concentration ${ }^{18}$. Generally, ST and SM are two key abiotic factors that control daily and seasonal variation in Rs across different vegetation types ${ }^{54}$. Previous study in a Tibetan Kobresia 

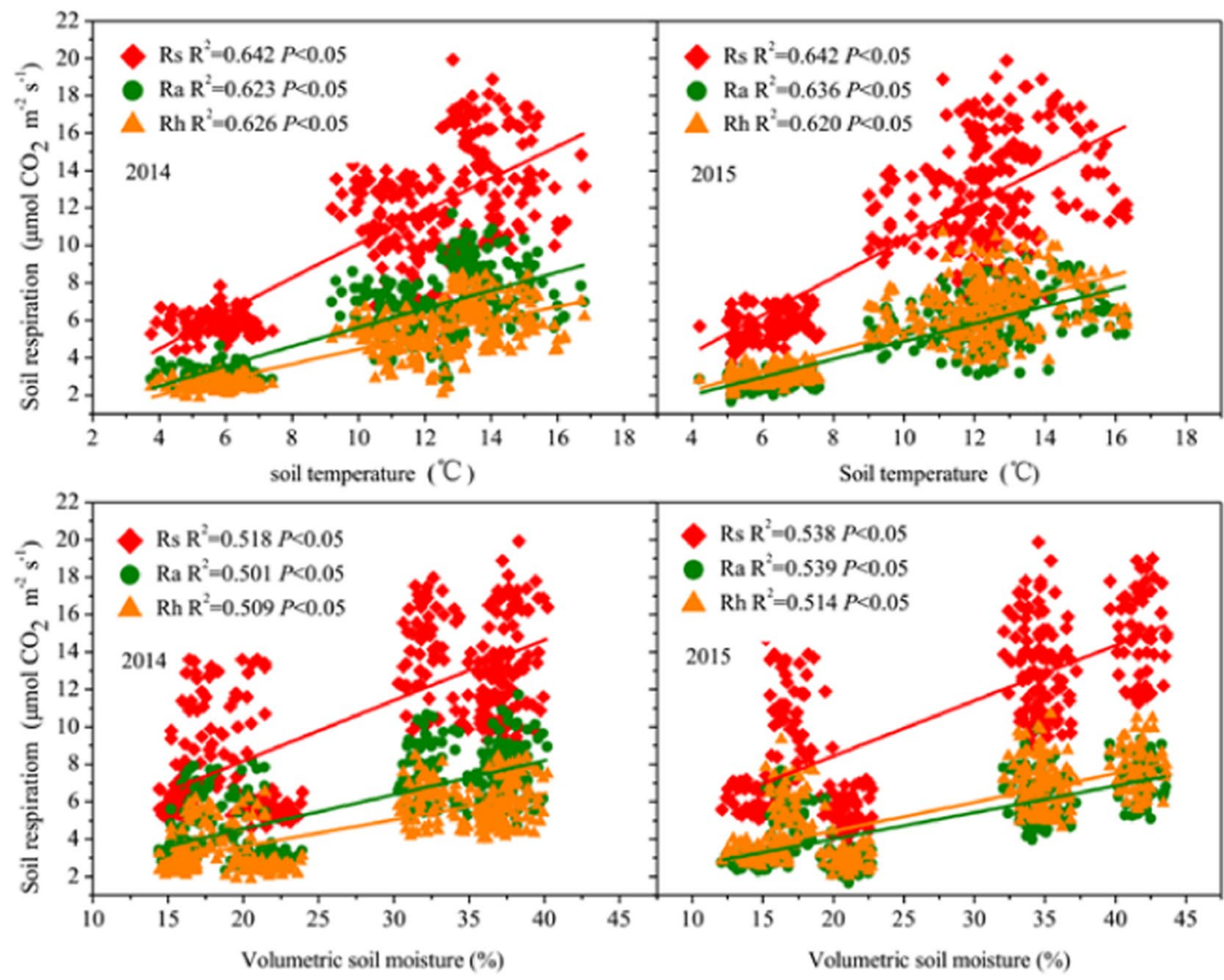

Figure 7. The relationships between soil respiration (Rs); autotrophic respiration ( $\mathrm{Ra})$; heterotrophic respiration $(\mathrm{Rh})$ and soil temperature and volumetric soil moisture.

\begin{tabular}{|c|c|c|c|c|}
\hline & Year & Equation & $\mathbf{R}^{2}$ & $P$-value \\
\hline \multirow{4}{*}{ Rs } & \multirow{2}{*}{2014} & $\mathrm{Rs}=0.003 * \mathrm{RCS}-0.002 * \mathrm{SOCS}_{10}+0.006 * \mathrm{SOCS}_{20}-3.344$ & 0.974 & 0.005 \\
\hline & & $\mathrm{Rs}=0.139 * \mathrm{SM} 10+0.659 * \mathrm{ST} 5-0.231$ & 0.690 & 0.008 \\
\hline & \multirow{2}{*}{2015} & Rs $=0.006 *$ RCS $-0.009 * \mathrm{SOCS}_{10}+0.011 * \mathrm{SOCS}_{20}+2.356$ & 0.976 & 0.002 \\
\hline & & $\mathrm{Rs}=0.144 * \mathrm{SM} 10+0.707 * \mathrm{ST} 5-0.686$ & 0.713 & 0.007 \\
\hline \multirow{4}{*}{$\mathrm{Ra}$} & \multirow{2}{*}{2014} & $\mathrm{Ra}=0.003 * \mathrm{RCS}-0.004 * \mathrm{SOCS}_{10}+0.004 * \mathrm{SOCS}_{20}+4.072$ & 0.960 & 0.005 \\
\hline & & $\mathrm{Ra}=0.078 * \mathrm{SM} 10+0.373 * \mathrm{ST} 5-0.18$ & 0.669 & 0.004 \\
\hline & \multirow{2}{*}{2015} & $\mathrm{Ra}=0.002 *$ RCS $-0.003 * \mathrm{SOCS}_{10}+0.005 * \mathrm{SOCS}_{20}-0.680$ & 0.945 & 0.008 \\
\hline & & $\mathrm{Ra}=0.07 * \mathrm{SM} 10+0.335 * \mathrm{ST} 5-0.351$ & 0.710 & 0.003 \\
\hline \multirow{4}{*}{$\mathrm{Rh}$} & \multirow{2}{*}{2014} & $\mathrm{Rh}=0.0001 * \mathrm{RCS}+0.002 * \mathrm{SOCS}_{10}+0.002 * \mathrm{SOCS}_{20}-7.417$ & 0.963 & 0.004 \\
\hline & & $\mathrm{Rh}=0.062 * \mathrm{SM} 10+0.286 * \mathrm{ST} 5-0.051$ & 0.675 & 0.000 \\
\hline & \multirow{2}{*}{2015} & $\mathrm{Rh}=0.004 * \mathrm{RCS}-0.006 * \mathrm{SOCS}_{10}+0.006 * \mathrm{SOCS}_{20}+3.036$ & 0.981 & 0.002 \\
\hline & & $\mathrm{Rh}=0.074 * \mathrm{SM} 10+0.372 * \mathrm{ST} 5-0.334$ & 0.686 & 0.000 \\
\hline
\end{tabular}

Table 2. Multiple linear regression equations of soil respiration (Rs), autotrophic respiration (Ra) and heterotrophic respiration (Rh) against root carbon storage (RCS), soil organic carbon storage in $0-10 \mathrm{~cm}$ layer $\left(\mathrm{SOCS}_{10}\right)$, soil organic carbon storage in $10-20 \mathrm{~cm}$ layer $\left(\mathrm{SOCS}_{20}\right)$, volumetric soil moisture at $10 \mathrm{~cm}$ depth (SM10) and soil temperature at $5 \mathrm{~cm}$ depth (ST5).

pastures found that ST5 had a stronger impact than did SM10 on growing season Rs ${ }^{22}$. However, studies conducted in temperate grassland and steppe grassland reported that SM10 had a stronger impact than did ST5 on growing season $\mathrm{Rs}^{24,55,56}$. In the present study, the SEM analysis revealed that soil temperature had a stronger effect than did soil moisture on Rs during the growing seasons. Soil temperature and moisture affect respiration by affecting respiratory enzymatic activity and substrate supply ${ }^{57}$. Generally, low temperature and soil water content limit the enzymatic activity and diffusion of soluble substrates; while high temperature and soil moisture also limit the enzymatic activity and the diffusion of oxygen, thus, both of which can suppress $\mathrm{Rs}^{57}$. Therefore, appropriate soil temperature and soil moisture are essential for soil respiration. Yan et al. ${ }^{58}$ reported that there was a threshold (14\%) at which the effects of volumetric soil water content on Rs changed, above which soil moisture is not the limiting factor of $\mathrm{Rs}^{58}$. Meanwhile, a previous study indicated that there 
was a threshold at which the effects of volumetric soil water content on soil respiration changed; that is, the two were positively correlated at soil water contents of $30 \%$ or lower, and negatively correlated at soil water contents of $>30 \%{ }^{59}$. In our study, the volumetric soil moisture in growing season was $25.3-27.2 \%$, which is no longer the factor that influences the diffusion of soluble substrates. Furthermore, the alpine meadow on the Qinghai-Tibetan Plateau is a temperature limited ecosystem ${ }^{60}$. The mean ST5 of the growing season was between $10.1^{\circ} \mathrm{C}$ and $10.9^{\circ} \mathrm{C}$, which may be below the threshold of soil temperature, and thus limit the respiratory enzymatic activity.

Although soil temperature and soil moisture had important effect on Rs, some previous researches indicated that some biotic parameters might have stronger effects on the Rs rate than do either SM10 or ST5 ${ }^{23,61}$. For example, previous studies showed that root and soil carbon storage significantly control the Rs through manipulating $\mathrm{Ra}$ and $\mathrm{Rh}$ in forest ecosystem ${ }^{23,62}$. Li et al. ${ }^{24}$ also revealed that the root and topsoil C pools were two most important factor that controlling the Rs in an alpine meadow on the Qinghai-Tibetan Plateau. In our study, the SEM results showed that $\mathrm{C}$ storage (in root, $0-10$ and $10-20 \mathrm{~cm}$ soil depths) have greater influences on Rs than do ST5 or SM10 (Fig. 5). Indicating that root C storage and C storage in topsoil (in $0-10$ and $10-20 \mathrm{~cm}$ soil depth) are two important factors driving Rs. This mainly attribute to the impacts of belowground $\mathrm{C}$ storage on the production of detritus and exudates for soil microbial activities ${ }^{23}$. C storage is a complex parameter representing the vegetation biomass and $\mathrm{C}$ concentration. The increase in belowground $\mathrm{C}$ storage was related to an increase in root biomass and thus increased Rs. We found that $\mathrm{N}$-addition significantly increased the root and soil carbon storage (Fig. 2). General linear regression analysis indicated that growing season Rs, $\mathrm{Ra}$ and $\mathrm{Rh}$ had significant positive correlation with root carbon storage and soil carbon storage (Fig. 6). The reason for this was the increased soil and root $\mathrm{C}$ storage that can meet the microbial demand for $\mathrm{C}$ source, and thereby increased Rh. Meanwhile, the combined root carbon storage, $0-10 \mathrm{~cm}$ and $10-20 \mathrm{~cm}$ soil layer carbon storage explained $97.4-97.6 \%$ variations in Rs; explained 94.5-96\% variations in Ra; and explained 96.3-98.1\% in Rh, which was higher than the combined soil temperature and soil moisture did (Table 2). Therefore, the growing season soil respiration and its components can be well predicted by the root and topsoil organic $\mathrm{C}$ storage in alpine meadow of the north-eastern Qinghai-Tibetan Plateau.

\section{Conclusion}

Short-term $\mathrm{N}$-addition can significantly increase the soil respiration and its components, $\mathrm{C}$ and $\mathrm{N}$ storage in plant, root and topsoil $(0-10 \mathrm{~cm}$ and $10-20 \mathrm{~cm}$ soil layer). Meanwhile, our results revealed that the stimulated effect of $\mathrm{N}$-addition on Rs was mainly due to the increase of $\mathrm{Rh}$ and Ra. In addition, the ecosystem $\mathrm{C}$ and $\mathrm{N}$ storage appears to saturate at a high rate of $\mathrm{N}$ addition $\left(216 \mathrm{~kg} \mathrm{~N} \mathrm{ha}^{-1} \mathrm{yr}^{-1}\right)$ in excess of the $\mathrm{N}$ saturation point $\left(180 \mathrm{~kg} \mathrm{~N} \mathrm{ha}^{-1} \mathrm{yr}^{-1}\right)$. However, the current study was a short term experiment, and how Rs and $\mathrm{C}$ storage respond to the long-term $\mathrm{N}$-addition remains unclear. Therefore, further studies should consider these for better understanding of the impacts of increasing $\mathrm{N}$ enrichment on $\mathrm{C}$ cycling in grassland ecosystem. The SEM results showed that $\mathrm{C}$ storage in root, $0-10$ and $10-20 \mathrm{~cm}$ soil depths have greater influences on soil respiration than do soil temperature or soil moisture. Meanwhile, multiple linear regression model showed the combined root carbon storage, topsoil carbon storage explained 97.4-97.6\% variations in Rs; explained 94.5-96\% variations in Ra; and explained 96.3-98.1\% in Rh, which was higher than the combined soil temperature and soil moisture did. Therefore, the growing season soil respiration and its components can be well predicted by the root and topsoil organic $\mathrm{C}$ storage in alpine meadow of the north-eastern Qinghai-Tibetan Plateau. The SEM results also indicated that soil temperature had a greater impact on growing season soil respiration than did volumetric soil moisture. Considering productive functions and ecosystem $\mathrm{C}$ storage, the optimum level of $\mathrm{N}$ fertilizer is $180 \mathrm{~kg} \mathrm{~N} \mathrm{ha}^{-1} \mathrm{yr}^{-1}$ in alpine meadow of the northeast margin of Qinghai-Tibetan Plateau.

\section{Materials and Methods}

Study area. The research was performed in an alpine meadow region of the northeast margin of QinghaiTibetan Plateau located in Zhuaxixiulong Township, Tianzhu Tibetan Autonomous County, Gansu Province, PR China $\left(37^{\circ} 11^{\prime} \mathrm{N}, 102^{\circ} 46^{\prime} \mathrm{E} ; 2960 \mathrm{~m}\right.$ a.s.l.). The area is approximately $180 \mathrm{~km}$ northwest of Lanzhou, PR China. The mean annual temperature in the study area was $0.13^{\circ} \mathrm{C}$ (varying from $-11.4^{\circ} \mathrm{C}$ in January to $11.2^{\circ} \mathrm{C}$ in July) and mean annual precipitation was $414.98 \mathrm{~mm}$, approximately $63.3-88.2 \%$ of the rainfall falling between June and September (climatological data from 1951 to 2016) ${ }^{63}$. In this region, the vegetation growing season is from May to October. The soil in the study area belongs to alpine chernozem. The soil organic carbon and total nitrogen con-

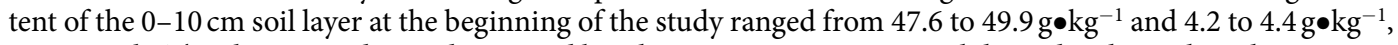
respectively. The alpine meadow is dominated by Elymus nutans, Poa crymophila And Kobresia humilis.

Experimental design. In the middle of June 2013 , we established three blocks $(18 \times 138 \mathrm{~m}$ per block $)$ as replicates. All blocks were located $10 \mathrm{~m}$ away from each other. Each block contained seven plots $(18 \mathrm{~m} \times 18 \mathrm{~m}$ per plot), with $2 \mathrm{~m}$ of walkway established between contiguous plots. $\mathrm{N}$ fertilizer was added as urea $\left(\mathrm{CO}\left(\mathrm{NH}_{2}\right)_{2}\right.$, $46.6 \% \mathrm{~N})$. The highest rate of $\mathrm{N}$ deposition that had occurred previously in the study area was $22.6 \mathrm{~kg} \mathrm{~N} \mathrm{ha}^{-1}$ in 2010 , and the annual rate of increase in $\mathrm{N}$ deposition in this region was $0.42 \mathrm{~kg} \mathrm{~N} \mathrm{ha}^{-1} \mathrm{yr}^{-164,65}$. Therefore, we chose seven $\mathrm{N}$-addition treatments in this study: 0 (N0), 54 (N1), 90 (N2), 126 (N3), 144 (N4), 180 (N5) and $216 \mathrm{~kg} \mathrm{~N} \mathrm{ha}^{-1} \mathrm{yr}^{-1}(\mathrm{~N} 6)$. The study was done using a randomized complete block design, and all of the N applications were randomly assigned to the seven plots of each block. The $\mathrm{N}$ fertilizer was evenly spread by hand in each plot in early July 2013, 2014 and 2015 following rainfall events. Our experiment was conducted from May to October in 2013, 2014 and 2015, respectively. The experimental grassland served as a local winter pasture; it was grazed from November to May by Tibetan sheep (6.67-7.22 head per hectare) and was fenced the remainder of the year. 
Field measurements and sampling. Soil respiration and its components. In late May of 2013, four intact, untrenched subplots $(1 \mathrm{~m} \times 1 \mathrm{~m})$ were randomly established in each plot. Meanwhile, we excavated a trench $(60 \mathrm{~cm}$ diameter $\times 70 \mathrm{~cm}$ deep, no root deeper than $70 \mathrm{~cm}$ ) on the outside edges of each untrenched subplot. For a total of twelve untrenched and trenched subplots of each $\mathrm{N}$ addition treatment, respectively. The location of each untrenched and trenched subplots were at least $1 \mathrm{~m}$ away from the margin to avoid edge effects. The trenches were lined with a nylon mesh bag $(0.038 \mathrm{~mm}$ mesh, $60 \mathrm{~cm}$ diameter $\times 75 \mathrm{~cm}$ deep $)$ to prevent root growth into the plots (but allow the movement of water, microorganism, organic matter and minerals). We removed the root using a 2 -mm sieve and then refilled the trenches with the root-free soil layer by layer ${ }^{25,66}$. Therefore, the $\mathrm{CO}_{2}$ efflux surveyed in the treated plots was $\mathrm{Rh}$, and $\mathrm{CO}_{2}$ efflux surveyed in the untrenched subplots was Rs. The difference between treated subplot and untrenched subplot was Ra. This root exclusion method has been widely used in the field to partition $\mathrm{Ra}$ and $\mathrm{Rh}^{25,66,67}$.

Soil $\mathrm{CO}_{2}$ flux was measured from May to October in 2014 and 2015 with a portable automated soil $\mathrm{CO}_{2}$ flux system (LI-8100 A, LI-COR Inc., Lincoln, USA). A PVC collars $(20 \mathrm{~cm}$ diameter and $15 \mathrm{~cm}$ height) were inserted into each untrenched and trenched subplots to a depth of $3-5 \mathrm{~cm}$ below the surface for soil $\mathrm{CO}_{2}$ flux measurement one day before each survey day. The soil was tamped outside of the collar to prevent air leakage. All soil $\mathrm{CO}_{2}$ flux measurements were taken between 09:00 and 14:00 on sunny days. Before the measurements, all plants in each PVC collar were clipped. The measurements were conducted twice a month (early and late in the month) for four days each time. ST5 and SM10 were measured simultaneously near each PVC collar along with the Rs measurement by a probe connected to the LI-8100 A.

Vegetation structure and soil properties. Vegetation and soil sampling were conducted in early September of 2014 and 2015. In each plot, eight $1 \mathrm{~m} \times 1 \mathrm{~m}$ quadrats were randomly established $1 \mathrm{~m}$ from the edge. In each quadrat, the height and density of each plant and the aboveground, belowground and litter biomass were investigated. Aboveground biomass was cut at ground level for species and all litter in each quadrat was collected by hand. We used a $10 \mathrm{~cm}$ inner diameter auger to measure the root biomass in $0-10,10-20$ and 20-30 cm soil layer in each harvested quadrat. We collected eight soil cores at each plot, and twenty-four soil cores per $\mathrm{N}$-addition treatment. We separated out the root by washing the soil samples within a $0.5-\mathrm{mm}$ mesh bag. The plant, litter and root samples were first dried at $105^{\circ} \mathrm{C}$ for $30 \mathrm{~min}$, and then dried at $65^{\circ} \mathrm{C}$ to constant weight. We used a cutting ring $\left(100 \mathrm{~cm}^{3}\right.$ volume $)$ to measure the soil bulk density at $0-30 \mathrm{~cm}$ soil depth in each of the harvested quadrat (i.e., the soil was divided into 3 layers of $10 \mathrm{~cm}$ each).

We used a $3.5 \mathrm{~cm}$ inner diameter auger to take soil samples in each harvested quadrat ( 3 layers of $10 \mathrm{~cm}$ each) to measure SOC, TN contents. Eight cores were collected in each plot, and twenty-four soil cores per N-addition treatment. Soil samples were air-dried and sieved to pass a $2 \mathrm{~mm}$ mesh sieve for testing the SOC and TN. Meanwhile, the surface layer $(0-10 \mathrm{~cm})$ soil was collected with a $3.5 \mathrm{~cm}$ inner diameter auger to measure the SMBC content in each harvested quadrat. Eight cores were collected in each plot, and twenty-four soil cores per $\mathrm{N}$-addition treatment. The soil samples were immediately sieved through a $2-\mathrm{mm}$ screen in the field and kept refrigerated.

Chemical analysis. The plant, litter, root and soil organic carbon contents were measured using a total organic carbon analyzer (Multi N/C 2100 s, Analytik Jena Germany). The plant, litter, root and soil total N contents were measured via the Kjeldahl method ${ }^{68}$. The SMBC content was measured via the chloroform fumigation extraction method. The carbon in the extract was measured through dichromate oxidation method, and the conversion coefficient was $0.38^{69}$.

Statistical analysis. The plant $\mathrm{C}$ storage and $\mathrm{N}$ storage were calculated by the methods of Fang et al. ${ }^{70}$; the soil organic $\mathrm{C}$ storage and $\mathrm{N}$ storage were calculated using the methods of $\mathrm{Ma}$ et al. ${ }^{71}$. The $\mathrm{C}$ storage and $\mathrm{N}$ storage in the alpine meadow ecosystem were considered the sum of the plant, root, litter and soil C storage and $\mathrm{N}$ storage, respectively.

Repeated-measures ANOVA was applied to compare the significant differences in Rs, Ra and Rh, biotic and abiotic variables among the $\mathrm{N}$-addition treatments. Considering the strong correlations among $\mathrm{C}$ and $\mathrm{N}$ storage in plant, litter, root, $0-10 \mathrm{~cm}$ soil layer, $10-20 \mathrm{~cm}$ soil layer, $20-30 \mathrm{~cm}$ soil layer, we used the PCA to determine the primary axes of covariation among the variables. Based on the PCA results, we chose the parameters with loading value greater than 0.900 and soil temperature and volumetric soil moisture as predictors to establish the SEM to identify the direct and indirect effect pathways on soil respiration. SEM was conducted with the Amos software program ver. 21.0.

Meanwhile, linear regression was conducted with the Origin software program ver. 8.5 to examine the relationships between soil respiration components (Rs, $\mathrm{Ra}$ and $\mathrm{Rh}$ ) and the following: root $\mathrm{C}$ storage, $0-10 \mathrm{~cm}$ soil layer C storage, $10-20 \mathrm{~cm}$ soil layer C storage, soil temperature and soil moisture. The equation was as follow:

$$
\mathrm{R}=\mathrm{a}+\mathrm{bx}
$$

where $\mathrm{R}$ is $\mathrm{Rs}$, $\mathrm{Ra}$, or $\mathrm{Rh}$; $\mathrm{x}$ is root $\mathrm{C}$ storage, $0-10 \mathrm{~cm}$ soil layer $\mathrm{C}$ storage, $10-20 \mathrm{~cm}$ soil layer $\mathrm{C}$ storage, soil temperature or soil moisture, and $\mathrm{a}$ and $\mathrm{b}$ are fitted parameters.

We used the following multiple linear regression to test the combined effect of root carbon storage, $0-10 \mathrm{~cm}$ layer carbon storage and 10-20 cm layer carbon storage on soil respiration rate (conducted with the Origin software program ver. 8.5):

$$
\mathrm{R}=\mathrm{c} \times \mathrm{RCS}+\mathrm{d} \times \mathrm{SOCS}_{10}+\mathrm{e} \times \mathrm{SOCS}_{20}+\mathrm{f}
$$

where R is Rs, Ra, or Rh, RCS is root carbon storage, $\mathrm{SOCS}_{10}$ is $0-10 \mathrm{~cm}$ layer carbon storage, $\mathrm{SOCS}_{20}$ is $10-20 \mathrm{~cm}$ layer carbon storage, and c, d, e and f are fitted parameters. 
We used the following multiple linear regression to test the combined effect of soil temperature and moisture on soil respiration rate (conducted with the Origin software program ver. 8.5):

$$
\mathrm{R}=\mathrm{g} \times \mathrm{ST} 5+\mathrm{h} \times \mathrm{SM} 10+\mathrm{i}
$$

where $\mathrm{R}$ is Rs, Ra, or Rh, ST5 is soil temperature at $5 \mathrm{~cm}$ depth, SM10 is volumetric soil moisture at $10 \mathrm{~cm}$ depth, and $\mathrm{g}, \mathrm{h}$, and $\mathrm{i}$ are fitted parameters.

All statistical analyses were conducted using the SPSS software program ver. 19.0 (SPSS, Chicago, IL).

\section{References}

1. Matson, P., Lohse, K. A. \& Hall, S. J. The Globalization of Nitrogen Deposition: Consequences for Terrestrial Ecosystems. Ambio 31, 113-119, https://doi.org/10.1579/0044-7447-31.2.113 (2002).

2. Dentener, F. et al. Nitrogen and sulfur deposition on regional and global scales: A multimodel evaluation. Global Biogeochemical Cycles 20, 16615-16615, https://doi.org/10.1029/2005GB002672 (2006).

3. Lamarque, J. et al. Assessing future nitrogen deposition and carbon cycle feedback using a multimodel approach: Analysis of nitrogen deposition. Journal of Geophysical Research Atmospheres 110, 2657-2677, https://doi.org/10.1029/2005JD005825 (2005).

4. Wolfe, A. P., Cooke, C. A. \& Hobbs, W. O. Are Current Rates of Atmospheric Nitrogen Deposition Influencing Lakes in the Eastern Canadian Arctic? Arctic Antarctic \& Alpine Research 38, 465-476, https://doi.org/10.1657/1523-0430(2006)38[465:ACROAN]2.0.CO;2 (2006).

5. Stevens, C. J., Dise, N. B., Mountford, J. O. \& Gowing, D. J. Impact of Nitrogen Deposition on the Species Richness of Grasslands. Science 303, 1876-1879, https://doi.org/10.1126/science.1094678 (2004).

6. Field, C. D. et al. The Role of Nitrogen Deposition in Widespread Plant Community Change Across Semi-natural Habitats. Ecosystems 17, 864-877, https://doi.org/10.1007/s10021-014-9765-5 (2014).

7. Tu, L. H. et al. Nitrogen addition stimulates different components of soil respiration in a subtropical bamboo ecosystem. Soil Biology \& Biochemistry 58, 255-264, https://doi.org/10.1016/j.soilbio.2012.12.005 (2013).

8. Thomas, R. Q., Brookshire, E. N. \& Gerber, S. Nitrogen limitation on land: how can it occur in Earth system models? Glob Chang Biol 21, 1777-1793, https://doi.org/10.1111/gcb.12813 (2015).

9. Samuel, E., Palmer, S. M. \& Chapman, P. J. Soil organic carbon stock in grasslands: Effects of inorganic fertilizers, liming and grazing in different climate settings. Journal of Environmental Management 223:74-84, https://doi.org/10.1016/j.jenvman.2018.06.013

10. Chen, J. et al. Differential responses of ecosystem respiration components to experimental warming in a meadow grassland on the Tibetan Plateau. Agricultural \& Forest Meteorology 220, 21-29, https://doi.org/10.1016/j.agrformet.2016.01.010 (2016b).

11. Cox, P. M., Betts, R. A., Jones, C. D., Spall, S. A. \& Totterdell, I. J. Acceleration of global warming due to carbon-cycle feedbacks in a coupled climate model. Nature 408, 184-187, https://doi.org/10.1038/35047138 (2000).

12. Dou, X. et al. Reforestation of Pinus massoniana alters soil organic carbon and nitrogen dynamics in eroded soil in south China. Ecological Engineering 52, 154-160, https://doi.org/10.1016/j.ecoleng.2012.12.099 (2013).

13. Frank, A. B. Carbon dioxide fluxes over a grazed prairie and seeded pasture in the Northern Great Plains. Environmental Pollution 116, 397-403, https://doi.org/10.1016/S0269-7491(01)00216-0 (2002).

14. Wang, R. et al. Temperature sensitivity of soil respiration: Synthetic effects of nitrogen and phosphorus fertilization on Chinese Loess Plateau. Science of the Total Environment 574, 1665-1673, https://doi.org/10.1016/j.scitotenv.2016.09.001 (2016).

15. Janssens, I. A. et al. Reduction of forest soil respiration in response to nitrogen deposition. Nature Geoscience 3, 315-322, https://doi. org/10.1038/ngeo844 (2010).

16. Eberwein, J. R., Oikawa, P. Y., Allsman, L. A. \& Jenerette, G. D. Carbon availability regulates soil respiration response to nitrogen and temperature. Soil Biology \& Biochemistry 88, 158-164, https://doi.org/10.1016/j.soilbio.2015.05.014 (2015).

17. Lagomarsino, A. \& Angelis, P. D. Drivers of increased soil respiration in a poplar coppice exposed to elevated $\mathrm{CO}_{2}$. Plant \& Soil 362 , 93-106, https://doi.org/10.1007/s11104-012-1261-0 (2013).

18. Cheng, Z. et al. Divergent Effects of Nitrogen Addition on Soil Respiration in a Semiarid Grassland. Scientific Reports 6, 33541, https://doi.org/10.1038/srep33541 (2016).

19. Chen, Z. et al. Extreme rainfall and snowfall alter responses of soil respiration to nitrogen fertilization: a 3-year field experiment. Global Change Biology 23, 3403, https://doi.org/10.1111/gcb.13620 (2017).

20. HÖGberg, P. et al. Large-scale forest girdling shows that current photosynthesis drives soil respiration. Nature 411(6839), 789-792, https://doi.org/10.1038/35081058 (2001).

21. Fóti, S. et al. Meta-analysis of field scale spatial variability of grassland soil CO2 efflux: Interaction of biotic and abiotic drivers. Catena 143, 78-89, https://doi.org/10.1016/j.catena.2016.03.034 (2016).

22. Liu, S., Schleuss, P. M. \& Kuzyakov, Y. Carbon and Nitrogen Losses from Soil Depend on Degradation of Tibetan Kobresia Pastures. Land Degradation \& Development 28, 1253-1262, https://doi.org/10.1002/ldr.2522 (2017).

23. Zhou, Z. et al. Predicting soil respiration using carbon stock in roots, litter and soil organic matter in forests of Loess Plateau in China. Soil Biology \& Biochemistry 57, 135-143, https://doi.org/10.1016/j.soilbio.2012.08.010 (2013).

24. Li, W., Wang, J., Zhang, X., Shi, S. \& Cao, W. Effect of degradation and rebuilding of artificial grasslands on soil respiration and carbon and nitrogen pools on an alpine meadow of the Qinghai-Tibetan Plateau. Ecological Engineering 111, 134-142, https://doi. org/10.1016/j.ecoleng.2017.10.013 (2018).

25. Zhang, C. et al. Effects of simulated nitrogen deposition on soil respiration components and their temperature sensitivities in a semiarid grassland. Soil Biology \& Biochemistry 75, 113-123, https://doi.org/10.1016/j.soilbio.2014.04.013 (2014).

26. Peng, Y. et al. Nonlinear response of soil respiration to increasing nitrogen additions in a Tibetan alpine steppe. Environmental Research Letters 12, 024018, https://doi.org/10.1088/1748-9326/aa5ba6 (2017).

27. Olsson, P. et al. Fertilization of boreal forest reduces both autotrophic and heterotrophic soil respiration. Global Change Biology, 10, 1745-1753, https://doi.org/10.1111/j.1365-2486.2005.001033.x (2010).

28. Group, I. et al. IPCC, Climate Change: The Physical Science Basis. South African Geographical Journal Being A Record of the Proceedings of the South African Geographical Society 92, 86-87, https://doi.org/10.1017/S1537592710003488 (2007).

29. Thornton, P. E. et al. Carbon-nitrogen interactions regulate climate-carbon cycle feedbacks: results from an atmosphere-ocean general circulation model. Biogeosciences Discussions 6:2099-2120, https://www.biogeosciences.net/6/2099/2009/ (2009).

30. Luo, Q. et al. The responses of soil respiration to nitrogen addition in a temperate grassland in northern China. Science of the Total Environment s 569-570, 1466-1477, https://doi.org/10.1016/j.scitotenv.2016.06.237 (2016).

31. Liu, X. R., Ren, J. Q., Li, S. G. \& Zhang, Q. W. Effects of Simulated Nitrogen Deposition on Soil Net Nitrogen Mineralization in the Meadow Steppe of Inner Mongolia, China. Plos One 10, e0134039, https://doi.org/10.1371/journal.pone.0134039 (2015).

32. Blagodatskaya, E., Yuyukina, S., Blagodatsky \& Kuzyakov, Y. Three-source-partitioning of microbial biomass and of $\mathrm{CO}_{2}$ efflux from soil to evaluate mechanisms of priming effects. Soil Biology \& Biochemistry 43(4), 778-786, https://doi.org/10.1016/j. soilbio.2010.12.011 (2011).

33. Kuzyakov, Y. Sources of $\mathrm{CO}_{2}$ efflux from soil and review of partitioning methods. Soil Biology \& Biochemistry 38, 425-448, https:// doi.org/10.1016/j.soilbio.2005.08.020 (2006). 
34. Uchida, Y., Nishimura, S. \& Akiyama, H. The relationship of water-soluble carbon and hot-water-soluble carbon with soil respiration in agricultural fields. Agriculture Ecosystems \& Environment 156, 116-122, https://doi.org/10.1016/j.agee.2012.05.012 (2012).

35. Peng, Y. \& Yang, Y. Allometric biomass partitioning under nitrogen enrichment: Evidence from manipulative experiments around the world. Scientific Reports 6, 28918, https://doi.org/10.1038/srep28918 (2016).

36. Peng, Y., Guo, D. \& Yang, Y. Global patterns of root dynamics under nitrogen enrichment. Global Ecology and Biogeography, 26, 102-14, https://doi.org/10.1111/geb.12508 (2017).

37. KyeHan, L. \& Jose, S. Soil respiration, fine root production, and microbial biomass in cottonwood and loblolly pine plantations along a nitrogen fertilization gradient. Forest Ecology \& Management 185, 263-273, https://doi.org/10.1016/s0378-1127(03)00164-6 (2003).

38. Guo, J. H. et al. Significant acidification in major Chinese croplands. Science 327, 1008, https://doi.org/10.1126/science.1182570 (2010).

39. Ramirez, K. S., Craine, J. M. \& Noah, F. Consistent effects of nitrogen amendments on soil microbial communities and processes across biomes. Global change biology 18, 1918-1927, https://doi.org/10.1111/j.1365-2486.2012.02639.x (2012).

40. Pregitzer, K. S., Burton, A. J., Zak, D. R. \& Talhelm, A. F. Simulated chronic nitrogen deposition increases carbon storage in Northern Temperate forests. Global Change Biology 14, 142-153, https://doi.org/10.1111/j.1365-2486.2007.01465.x (2008).

41. Neff, J. C. et al. Variable effects of nitrogen additions on the stability and turnover of soil carbon. Nature 419, 915-917, https://doi. org/10.1038/nature01136 (2002).

42. Mack, S., Bret-Harte, S. \& Chapin Ecosystem carbon storage in arctic tundra reduced by long-term nutrient fertilization. Nature 431, 440-443, https://doi.org/10.1038/nature02887 (2004).

43. Wang, C., Wang, G., Liu, W. \& Wang, Q. Effects of fertilization gradients on plant community structure and soil characteristics in alpine meadow. Acta Ecologica Sinica 10, 3103-3113, https://doi.org/10.5846/stxb201202200232 (2013).

44. Dong, W., Duan, Y., Wang, Y. \& Hu, C. Reassessing carbon sequestration in the North China Plain via addition of nitrogen. Science of the Total Environment s 563-564, 138-144, https://doi.org/10.1016/j.scitotenv.2016.04.115 (2016)

45. Shi, F. S., Wu, Y., Wu, N. \& Luo, P. Different growth and physiological responses to experimental warming of two dominant plant species Elymus nutans and Potentilla anserina in an alpine meadow of the eastern Tibetan Plateau. Photosynthetica 48, 437-445, https://doi.org/10.1007/s11099-010-0058-8 (2010).

46. Riggs, C. E., Hobbie, S. E., Bach, E. M., Hofmockel, K. S. \& Kazanski, C. E. Nitrogen addition changes grassland soil organic matter decomposition. Biogeochemistry 125, 203-219, https://doi.org/10.1007/s10533-015-0123-2 (2015).

47. Li, G. \& Sun, S. Plant clipping may cause overestimation of soil respiration in a Tibetan alpine meadow, southwest China. Ecological Research, 3, 497-504, https://doi.org/10.1007/s11284-011-0806-7 (2011).

48. Kato, T. et al. Carbon dioxide exchange between the atmosphere and an alpine meadow ecosystem on the Qinghai-Tibetan Plateau, China. Agricultural \& Forest Meteorology 124, 121-134, https://doi.org/10.1016/j.agrformet.2003.12.008 (2004).

49. Chen, D., Li, J., Lan, Z., Hu, S. \& Bai, Y. Soil acidification exerts a greater control on soil respiration than soil nitrogen availability in grasslands subjected to long-term nitrogen enrichment. Functional Ecology 30, 658-669, https://doi.org/10.1111/1365-2435.12525 (2016a).

50. Berryman, E. M. et al. Complex terrain alters temperature and moisture limitations of forest soil respiration across a semiarid to subalpine gradient. Journal of Geophysical Research Biogeosciences 120, 707-723, https://doi.org/10.1002/2014JG002802 (2015).

51. Marschner, P. Mineral Nutrition of Higher Plants 3rd edn (London: Academic) (2011).

52. Jennings, B. W. \& Watmough, S. A. The Impact of Invasive Earthworms on Soil Respiration and Soil Carbon Within Temperate Hardwood Forests. Ecosystems 19, 1-13, https://doi.org/10.1007/s10021-016-9977-y (2015).

53. Knowles, J. F., Blanken, P. D. \& Williams, M. W. Soil respiration variability across a soil moisture and vegetation community gradient within a snow-scoured alpine meadow. Biogeochemistry 125, 185-202, https://doi.org/10.1007/s10533-015-0122-3 (2015).

54. Raich, J. W. \& Tufekciogul, A. Vegetation and soil respiration: Correlations and controls. Biogeochemistry 48, 71-90, https://doi. org/10.1023/a:1006112000616 (2000).

55. Stielstra, C. M. et al. Climatic and landscape influences on soil moisture are primary determinants of soil carbon fluxes in seasonally snow-covered forest ecosystems. Biogeochemistry 123, 447-465, https://doi.org/10.1007/s10533-015-0078-3 (2015).

56. Wang, D., Wu, G. L., Liu, Y., Yang, Z. \& Hao, H. M. Effects of grazing exclusion on CO2 fluxes in a steppe grassland on the Loess Plateau (China). Ecological Engineering 83, 169-175, https://doi.org/10.1016/j.ecoleng.2015.06.017 (2015).

57. Davidson, E. A., Janssens, I. A. \& Luo, Y. On the variability of respiration in terrestrial ecosystems: moving beyond Q10. Global Change Biology 12, 154-164, https://doi.org/10.1111/j.1365-2486.2005.01065.x (2006).

58. Yan, L., Chen, S., Huang, J. \& Lin, G. Differential responses of auto- and heterotrophic soil respiration to water and nitrogen addition in a semiarid temperate steppe. Global Change Biology, 16(8), 2345-2357, https://doi.org/10.1111/j.1365-2486.2009.02091.x (2010).

59. Li, W. et al. Analysis of soil respiration under different grazing management patterns in the alpine meadow-steppe of the Qinghai Tibet Plateau. Acta Prataculturae Sinica 10, 22-32, https://doi.org/10.11686/cyxb2015152 (2015).

60. Qiu, J. China: The third pole. Nature 454, 393-396 (2008).

61. Luan, J., Liu, S., Zhu, X. \& Wang, J. Soil carbon stocks and fluxes in a warm-temperate oak chronosequence in China. Plant \& Soil 347, 243, https://doi.org/10.1007/s11104-011-0842-7 (2011).

62. Jassal, R., Black, T., Novak, M., Gaumont-Guay, D. \& Nesic, Z. Effect of soil water stress on soil respiration and its temperature sensitivity in an 18-year-old temperate Douglas-fir stand. Global Change Biology 14, 1305-1318, https://doi. org $/ 10.1111 / j .1365-2486.2008 .01573 . x(2010)$.

63. Li, W., Liu, Y., Wang, J., Shi, S. \& Cao, W. Six years of grazing exclusion is the optimum duration in the alpine meadow-steppe of the north-eastern Qinghai-Tibetan Plateau. Scientific Reports 8, 17269, https://doi.org/10.1038/s41598-018-35273-y (2018).

64. Liu, X. et al. Nitrogen deposition and its ecological impact in China: an overview. Environmental Pollution 159, 2251-2264, https:// doi.org/10.1016/j.envpol.2010.08.002 (2011).

65. Liu, X. et al. Enhanced nitrogen deposition over China. Nature 494, 459-462, https://doi.org/10.1038/naturel1917 (2013).

66. Li, X., Fu, H., Guo, D., Li, X. \& Wan, C. Partitioning soil respiration and assessing the carbon balance in a Setaria italica (L.) Beauv. Cropland on the Loess Plateau, Northern China. Soil Biology \& Biochemistry 42, 337-346, https://doi.org/10.1016/j. soilbio.2009.11.013 (2010).

67. Moyano, F. E., Kutsch, W. L. \& Schulze, E. D. Response of mycorrhizal, rhizosphere and soil basal respiration to temperature and photosynthesis in a barley field. Soil Biology \& Biochemistry 39, 843-853, https://doi.org/10.1016/j.soilbio.2006.10.001 (2007).

68. Bradford, J. M. Methods of Soil Analysis: Part 1-Physical and Mineralogical Methods (1986).

69. Vance, E. D., Brookes, P. C. \& Jenkinson, D. S. An extraction method for measuring soil microbial biomass C. Soil Biology \& Biochemistry 6, 703-707, https://doi.org/10.1016/0038-0717(87)90052-6 (1987).

70. Fang, J. Y., Guo, Z. D., Piao, S. L. \& Chen, A. P. Terrestrial vegetation carbon sinks in China, 1981-2000. Science China Earth Sciences 50, 1341-1350, https://doi.org/10.1007/s11430-007-0049-1 (2007).

71. Ma, A., He, N., Yu, G., Ding, W. \& Peng, S. Carbon storage in Chinese grassland ecosystems: Influence of different integrative methods. Scientific Reports 6, 21378, https://doi.org/10.1038/srep21378 (2016).

\section{Acknowledgements}

This study was supported by the National Key Research and Development Program of China (2018YFD0502400 and 2016YFC0400306), Modern Agricultural Industry Technology System of China (CARS-35), Fostering Foundation for the Excellent Ph.D. Dissertation of Gansu Agricultural University (YBPY2016001) and Key Laboratory of Superior Forage Germplasm in the Qinghai-Tibetan Plateau (2017-ZJ-Y12). 


\section{Author Contributions}

W.L., S.L.S. and W.X.C. conceived this study and designed the experiments. W.L., J.L.W., X.L.L., S.L.W. and W.H.L. conducted the experiment. W.L. and J.L.W. analyzed the data and prepared figures. W.L. wrote the paper. W.L., W.X.C. and S.L.S. edited the language. All authors interpreted the results and reviewed the manuscript.

\section{Additional Information}

Competing Interests: The authors declare no competing interests.

Publisher's note Springer Nature remains neutral with regard to jurisdictional claims in published maps and institutional affiliations.

(c) (i) Open Access This article is licensed under a Creative Commons Attribution 4.0 International License, which permits use, sharing, adaptation, distribution and reproduction in any medium or format, as long as you give appropriate credit to the original author(s) and the source, provide a link to the Creative Commons license, and indicate if changes were made. The images or other third party material in this article are included in the article's Creative Commons license, unless indicated otherwise in a credit line to the material. If material is not included in the article's Creative Commons license and your intended use is not permitted by statutory regulation or exceeds the permitted use, you will need to obtain permission directly from the copyright holder. To view a copy of this license, visit http://creativecommons.org/licenses/by/4.0/.

(C) The Author(s) 2019 